\title{
THE CONCEPT OF STATEHOOD IN UNITED NATIONS PRACTICE *
}

\section{ROSALYN COHEN $\dagger$}

The topic of "statehood under international law" has long been a favorite with jurists. The problem of what constitutes a "state" has been extensively examined and discussed, but all too often in absolutist terms confined to drawing up lists of criteria which must be met before an entity may be deemed a "state." The very rigidity of this approach implies that the term "state" has a fixed meaning which provides an unambiguous yardstick for measuring without serious fear of error, the existence of international personality. The framework of examination being thus constricted, traditional inquiry has endeavored to meet some of its inadequacies by ancillary discussions on the possibility of a "dependent state" in international law, of the desirability of universality in certain organizations set up by the international community, and of the rights of peoples to national self-determination. It would appear, however, that these questions, far from being ancillary, are integral to any discussion of "statehood." Even the language of the law-or perhaps especially the language of the law-contains ambiguities which are inherent in any language system, and the difficulties presented by this fact can only be resolved by an analysis which takes full cognizance of the contextual background. Thus, when examining what is meant by the word "state," an appraisal of the community interests which will be affected by the decision to interpret it in one way rather than in another is necessary. Discussions, for example, of whether a "dependent state" can exist under international law become meaningless unless there is first an examination of whether the community of nations would find it appropriate, in the light of its long range objectives, to afford the rights which follow from "statehood" to entities fettered by restrictions which impair their independence. Consideration must also be given to whether some forms of dependency may give rise to an affirmative answer to this question, and others to a negative answer. It is equally necessary to emphasize

* The author wishes to express her sincere gratitude to Professor Myres S. McDougal, of Yale Law School, and to Dr. Oscar Schachter, Director in the Office of Legal Affairs, the United Nations, for their encouragement and advice during the preparation of this Article. The views contained in this Article, however, do not necessarily reflect their own.

i B.A. 1958, LL.B. 1959, Cambridge; Commonwealth Fund Fellow at Yale University Law School. 
that the decision-maker here is the community at large rather than any one state. We are concerned, in trying to give meaningful content to the term "state," with the interests of mankind in conducting an ordered, regulated, peaceful society, in which individual liberties and human dignity may be promoted.

The principles upon which the United Nations is founded reflect the interests of the general community, since that organization consists of the vast majority of entities which have been generally recognized as full members of the international community. The political organs of the United Nations ${ }^{1}$ have the authority to admit applicants to membership in that organization, subject, inter alia, to the condition that the applicant be a state. In interpreting this term all the considerations mentioned above must be taken into account. At the same time, these organs must consider certain policy problems specifcally relevant to the United Nations which cannot be resolved merely by reference to the other prerequisites of admission: those of being "peace-loving" and "able and willing" to fulfill the obligations of the Charter. These problems will be refined and discussed below.

In performing the very difficult task of interpreting the juridical criteria of statehood-criteria which are less well defined than is commonly thought - the political organs of the United Nations may be called upon to play several different roles. They may be entrusted with the task of regulating membership in the United Nations itself or in its specialized agencies, or of regulating the appearance of entities before its own organs under the provisions of the Charter or before the International Court of Justice. Consequently, not only do community goals have to be taken into consideration as keys to the interpretation of the criteria of statehood, but so do the various claims and tasks to which the acknowledgment of statehood is relevant.

It is a fashionable view among both lawyers and political scientists that the political organs of the United Nations have completely ignored juridical criteria when they have been called upon to assess statehood, and that they have granted or withheld recognition of statehood solely on political grounds which have borne little relation to community interests. This view is most dubious, and would appear to arise from an inadequate appreciation of contextual factors and an overemphasis on the so-called "package deal" as representative of United Nations practice. Further, legal criteria are open to differing interpretations without giving rise to the charge of mala fides, and there is some evidence that variations in interpretation have not been capricious or

I I.e., those organs performing a prescribing function, namely, the General Assembly, Security Council, Trusteeship Council, Economic and Social Council, and Secretariat. 
arbitrary, but have followed certain defined patterns, according to whether the claim of statehood has been made to obtain full membership in the United Nations or some lesser benefits. This in no way denies the validity of the legal criteria of statehood; on the contrary, it insists that the political organs of the United Nations have chosen to adhere to them, and that recognition of this fact has been blurred through fallacious assumptions as to the true significance of interpretations which are variable rather than absolute. To interpret guiding symbols in the light of differing claims affecting community interests is not to deny the sanctity of law but to confirm it in its most efficacious sense.

In the discussion to follow, it will be attempted, by examination of United Nations practice, to establish the general hypothesis suggested above. In addition, there will be recommended certain considerations to be taken into account in the future, when the political organs will again be called upon-in ever-changing world conditionsto interpret juridical criteria in the context of differing claims, for the furtherance of community interests.

Under traditional international law it has been commonly assumed that four criteria must be met before an entity can be said to be a "state." In the words of the Montevideo Convention on the Rights and Duties of States, "the state as a person of international law should possess the following qualifications: $a$ ) a permanent population; $b$ ) a defined territory; $c$ ) government; and $d$ ) capacity to enter into relations with the other states." 2 Attempts at more detailed and sophisticated definitions have proved abortive. ${ }^{3}$

The Charter of the United Nations itself mentions the term "state" no fewer than thirty-one times. ${ }^{4}$ These provisions form at least part of the framework for any claims of statehood that may be made before that organization, since claims as to the existence of statehood are not made in vacuo, but are tied to specific, related claims. These, stemming from the initial and comprehensive claim of possession of the attributes of statehood, include claims to be admitted to the United Nations, ${ }^{5}$ to appear before specific organs of the United

2 Dec. 26, 1933, art. 1, 49 Stat. 3097, T.S. No. 881.

3 For example, India proposed that a definition of "state" be included in the Draft Declaration on the Rights and Duties of States, U.N. Doc. No. A/CN.4/2, at 170 (1948), but the International Law Commission "concluded that no useful purpose would be served ... " by such a definition, International Law Comm'n, Report, U.N. GEN. Ass. OFF. REc. [hereinafter cited as GAOR] 4th Sess., Supp. No. 10, para. 49 (A/925) (1949).

4 In art. 2, paras. 47 ; art. 3 ; art. 4, paras. $1-2$; art. 11, para. 2 ; art. 32; art. 35, para. 2 ; art. 43 , para. 3 ; art. 50 ; art. 52 , para. 3 ; art. 53 , paras. $1-2$; art. 59 ; art. 79 ; art. 80, para. 1; art 81; art. 93, para. 2; art. 107; and art. 110, paras. 1-4.

5 U.N. ChARTER art. 4. 
Nations, ${ }^{6}$ to participate in certain specialized agencies, to bring matters affecting peace and security to the notice of the United Nations, ${ }^{7}$ to be a party to the Statute of the International Court of Justice, ${ }^{8}$ and to achieve other benefits. ${ }^{9}$

In analyzing the treatment which claims of statehood have received before the United Nations and related international organs, this Article will stress the quality of the judgments which have concerned membership in the United Nations itself, discussing briefly the criteria of permanent population, defined territory, and stable and effective government. Particularly careful consideration will be given to the more ambiguous requirement of independence, the treatment of which has been responsible for most of the allegedly "politically motivated" decisions on admission to the United Nations. Claims to membership in specialized agencies or to be a party to the Statute of the International Court of Justice will be discussed insofar as they may illustrate the more basic claim of statehood and reasons will be suggested why this claim must receive more flexible treatment vis-à-vis these organizations than toward the United Nations itself. Certain other claims will be similarly analyzed. Finally, an attempt will be made to evaluate the information presented and to draw some conclusions as to the proper application of the juridical concept of statehood in United Nations practice.

\section{Claim to Admission to the United Nations}

An entity which considers itself a state under international law may apply for membership in the United Nations. In view of the facts that the United Nations is today of nearly universal membership, ${ }^{10}$ and that a member of the United Nations acquires automatic membership in the General Assembly, ${ }^{11}$ gains opportunities for periodic representation on the other organs ${ }^{12}$ (including the Security Council), and automatically becomes a party to the Statute of the International

6 U.N. Charter art. 32.

7 U.N. Charter art. 35, para. 2.

8 U.N. CharTER art. 93, para. 2.

9 Thus the claim of statehood may arise in other contexts not immediately suggested by the charter, e.g., the claim for recognition as a state by existing members of the international community, the claim to protection of its nationals and control over its resources, the claim to succession to certain rights and assets of a parent state, and the claim that certain changes do not affect identity. In theory, each of these claims could arise within the context of the effect of United Nations practice upon international law. However, this Article only attempts to deal with those areas where the issue has arisen both directly and sharply enough to warrant examination.

${ }_{10}$ As of October 30,1960 , ninety-nine states were members of the United Nations. Since that time, several newly emerged states have been proposed for membership, but none has been admitted.

11 U.N. CEARTER art. 9.

12 U.N. CEARTER arts. 23, 61, 86. 
Court of Justice, ${ }^{13}$ this may be characterized as a claim to comprehensive participation.

A study of United Nations practice in relation to this claim will reveal a surprisingly close adherence to the traditional legal criteria of statehood. In those cases where deviations from the traditional norms appear to have taken place, such deviations may easily be explained in terms of permissible interpretation under Article 4(1) or of flexibility or uncertainty in the criteria themselves. ${ }^{14}$

Claims for admission to comprehensive membership in the United Nations should be divided into those for original membership in the world organization and those for subsequent membership.

\section{Claim to Original Membership}

This claim deserves only brief attention, since it does not fall within the field of United Nations "practice" but represents a sui generis case arising from pre-1946 circumstances and agreements.

The Charter of the United Nations divides members into two classes-original members and elected members. Article 3 states that "The original Members of the United Nations shall be the States which, having participated in the United Nations Conference on International Organization at San Francisco, or having previously signed the Declaration by United Nations of 1 January 1942, sign the present Charter and ratify it in accordance with Article 110."

The appearance of Byelorussia and the Ukraine at the San Francisco Conference was the outcome of a compromise on a point that had been in issue since before the Dumbarton Oaks discussions. ${ }^{15}$ The United States, supported by Great Britain, had urged at Dumbarton Oaks the inclusion of "associated states," which were classified as those which had been invited to the United Nations economic conferences and which were assisting the belligerents though not technically at war. ${ }^{18}$ The Soviet Union, as the price for this, requested the inclusion as original members of all sixteen of the newly autonomous Soviet

13 U.N. ChARTER art. 93, para. 1.

14 Cf. Robinson, Metamorphosis of the United Nations, 94 ReceuII DES Cours 497, 550-51 (1958), where it is contended that the "package deal" arranging the simultaneous admission of eighteen states ignored all criteria for eligibility save possibly that of statehood, and that the handling of the transformation of Syria and Egypt into the United Arab Republic did away with legal reference even to statehood. As to the latter, see Cotran, Some Legal Aspects of the Formation of the United Arab Republic and the United Arab States, 8 InT'L \& CoMP. L.Q. 346 (1959).

15 See the earlier Soviet request for special representation of certain Soviet Republics on the Allied War Crimes Commission, U.S. Dep'T of STATE, PoSTWAR Foreign Poltcy Preparation, 1939-1945, at $318 \mathrm{n} .19$ (1949). It was generally felt that the autonomy decree of February 1944 tied in with this move. See Russel \& MUTtigr, A History of the United Nations Charter 361 (1958).

16 Six Iatin American states, Egypt, Iceland, and the Provisional French Government (which in actual fact joined as a signatory of the Declaration on January 1, 1945 ) were in this class. See Russell \& MUTHER, op. cit. supra note 15, at 508. 
Republics. ${ }^{17}$ Ultimately it was the vexed point of voting in the Security Council which was used by the United States as the bargaining lever. ${ }^{18}$ When, at Yalta, the U.S.S.R. acceded to the United States voting proposals, it reaffirmed its desire for the admission of the Soviet Republics, but stated that at the present time it would be satisfied with the admission of two or three republics. ${ }^{19}$ The United States and Great Britain agreed to this request, since, having obtained both Russian consent on Security Council voting and a reduced demand for Soviet membership, they felt that the extra votes in the Assembly would not make much practical difference.

The position of India and the Philippines among the original members was also anomalous. At no time was there any serious opposition to their inclusion. At the very early stages, when the United States was engaged in formulating a draft constitution, it was suggested that "all self-governing States and Dominions, accepting the obligations of membership, shall be Members of the International Organization." 20 The Staff Charter, which was drafted in the summer of 1943, contained a provision on membership referring to "independent states." 21 India and the Philippines were apparently considered to be covered by this provision. ${ }^{22}$ At the San Francisco Conference itself the Philippine delegate requested that the term "nation" be used in the committee draft instead of "state." ${ }^{23}$ The

17 The first formal request was not made public, for fear it would jeopardize negotiations. U.S. DEP'T OF STATE, op. cit. supra note 15, at 317-18. President Roosevelt later declared to the Senate Committee on Foreign Relations that he would ask for membership of all forty-eight states if Stalin insisted on membership for all sixteen republics. The status of the republics was defined by the Soviet Autonomy Decree of February 1, 1944, which allowed the republics "to enter into direct relation with foreign States."' See also Aufricht, Principles and Practices of Recognition by International Organizations, 43 AM. J. INT'L L. 679, 695-98 (1949).

18 The main conflict in this area had centered about defining the cases to which the veto should apply and deciding whether a permanent member party to a dispute should have the right to vote. Yalta Conference, Third Plenary Meeting, Bohlen Minutes, [1945] FoREIGN REL. U.S. 661-63 (1955).

19 Those suggested were White Russia, the Ukraine, and Lithuania. Yalta Conference, Fourth Plenary Meeting, Bohlen Minutes, id. at 712. The last was eventually dropped by agreement. See Memorandum of Decisions Reached at the Crimean Conference in the Matter of the Two Soviet Republics, id. at 991-92; RUSSELL \& MUTHER, op. cit. supra note 15, at 536-37.

20 Russell \& MUteer, op. cit. supra note 15 , at 350 . In the Draft Constitution "qualified" was substituted for "self-governing." See U.S. DEP'T OF STATE, op. cit. supra note 15 , at 473 .

21 Id. at 526.

22 India did not become a self-governing dominion within the British Commonwealth until August 15, 1947. However, at the time of the San Francisco Conference its acquisition of statehood as a self-governing dominion had been conceded and only awaited implementation by formal parliamentary action. President Truman proclaimed the independence of the Philippine Commonwealth on July 4, 1946.

23 Doc. No.. 242, I/2/11, 7 U.N. CoNf. INT'L Org. Docs. 24 (1945). This request was met in Committee I/ 2 by providing that "all nations participating in this Conference should be regarded as initial members of the Organization." Doc. No. 606, $I / 2 / 43$, id. at 121 ; Doc. No. $1074, \mathrm{I} / 2 / 76$, id. at 288 . 
Coordination Committee, feeling that uniformity of expression was of paramount importance, finally decided that all participants in the Conference should be considered "states." And in the Charter text itself the word "nation" was dropped in favor of "state." 24

India had long been a participant in world affairs. She held a position of importance in the British Commonwealth, had an exemplary war record, and had played an active role in the League; the part played by the Philippines in the war was equally relevant. To have denied them original membership would have been both undesirable and embarrassing. ${ }^{25}$

It may be seen, therefore, that with regard to the claim of original membership, decisions were taken for the admission of territorial communities whose accurate description at that time fell short of meeting traditional legal criteria. There never was any pretense of adherence, and to treat this as a sui generis case not truly indicative of United Nations practice-where at least there is a formal effort at adherence to the criteria-would seem to be a more realistic appraisal than to suggest that 'the word 'state' is not to be understood in its usual legal sense." 26

\section{Claim to Subsequent Membership}

In analyzing the treatment received by the large number of claimants in this classification, it is more instructive to consider United Nations practice in terms of each of the traditional legal criteria of statehood than to examine the treatment given the applications of each claimant.

\section{Permanent Population}

No claims in the practice of the United Nations have raised questions concerning this criterion. It might be suggested that the

24 Though "nation" was retained for more general reference, such as in the Preamble and Article 1. See RUSSELL \& MUTHER, op. cit. supra note 15, at 928 n.60.

25 For India's status in the early years of the United Nations, see Liang, $A d$ mission of the Indian States to the United Nations, 43 AM. J. INT'L L. 134, 144-54 (1949). Lebanon and Syria likewise participated in the Conference, although the French Government at that time took the view that its responsibilities were not yet terminated in Lebanon and Syria.

26 Goodrich \& Hambro, The Charter of the United Nations 124 (1949). See also KeISEN, THE LAw of THE UNITED Natrons 59-60 (1950). It is significant that article 1, paragraph 2, of the Covenant of the League of Nations had used the term "any fully self-governing State, Dominion or Colony." The refusal to follow this precedent and the misuse of the word "state" to cover entities lacking state character is possibly to be explained by the traditional dualist theory that only states may be subjects of international law. In actual fact no colony ever applied for membership in the League of Nations. As is pointed out by Rudzinski, Admission of New Members, 1952 INT'I Conc. 143, 145, the questionnaire used by the League in the normal admission procedure of investigation spoke of "a nation" and asked whether it was fully selfgoverning. In practice this meant at least a dominion, such as Ireland in 1923. 
existence of a permanent population would be relevant if Antarctica were to claim statehood.

\section{Defined Territory}

Much of the controversy which surrounded the application of the newly proclaimed state of Israel for membership in the United Nations stemmed from doubts as to whether it met the requirement of a defined territory. The Arab states, led by Syria, contended that since Israel's borders were contested, its statehood must be denied. ${ }^{27}$ The United Kingdom also offered this as the reason for its refusal either to recognize the state of Israel or to support its application for admission. ${ }^{28}$ Other representatives, construing the territorial requirement more liberally, thought that the General Assembly resolution of $1947^{29}$ conferred territory upon Israel and that it did not matter that certain details as to the delimitation of this territory remained unsettled. ${ }^{30}$ When, after postponement of the issue, consideration of the application was taken up again, Israel's request for membership was granted. ${ }^{31}$

In other cases the requirement of a "defined territory" has tended to be blurred by the existence of territorial disputes and other factors; ${ }^{32}$ and in yet other cases it has been used as something of an automatic argument in the cold war. ${ }^{33}$ Nevertheless, the only unam-

27 U.N. SeCURITY CouncIL OFF. Rec. [hereinafter cited as SCOR] 3d year, 385th meeting 3-4 (S/1121) (1948); SCOR 3d year, 386th meeting 19-20 (S/PV. 386) (1948). See also statements by Egypt, GAOR 3d Sess. pt. 2, Plenary 311-12 (A/855) (1949); GAOR 3d Sess. pt. 2, Ad Hoc Pol. Comm. 267 (A/818) (1949); by Iraq, id. at 181, 289; by Lebanon, id. at 107, 220, 222; by Saudi Arabia, id. at 294-95; by Yemen, $i d$. at 305-06; and by Pakistan, $i d$. at 321 .

28 SCOR 3d year, 383d meeting 15-16 (S/1093) (1948).

29 GAOR $2 d$ Sess., Resolutions, No. 181(II), at $131^{\circ}$ (1947).

30 E.g., Uraguay, GAOR 3d Sess., Ad Hoc Pol. Comm. 297 (A/18) (1949); U.S.S.R., SCOR 3d year, 383d meeting 22 (S/1093) (1948); SCOR 3d year, 386th meeting 30-31 (S/1121) (1948). See especially the speech by Representative Jessup of the United States, SCOR 3d year, 383d meeting 9 (S/1093) (1948), noting that both "reason and history" demand no precise delimitations of the boundaries of a territory.

31 SCOR 4th year, 414th meeting 14 (S/1267) (1949). A fair assessment of the legal dispute in this case requires some reference to the political pressures of the Jews in America and the Arab states on England and France. Nor was the Soviet Union unaffected by the Israeli-Arab disputes.

32 Thus France couched its objections to the admission of Siam, with which it had a territorial dispute, in terms of the continuation of a state of war between the two countries caused by Siam's aggression in Indo-China. In actual fact, Siam's agreement to participate in a projected conciliation commission was the sine qua non of French support for her application, and this support was ultimately obtained. SCOR 1st year, 2d ser., 83d meeting 562, Supp. No. 4, at $43-47$ (S/23), (S/14), (S/21) (1946).

33 Thus Greece's objection to the admission of Albania, whose application came in the coldest era of the cold war, was that a disputed claim between them to northern Epirus was still outstanding. SCOR 1st year, $2 \mathrm{~d}$ ser., Supp. No. 4, at $20-24(\mathrm{~S} / 123)$ (1946). The issue of defined territory constantly arose with regard 
biguous case which could be cited in support of the contention that power politics has caused the United Nations to ignore this traditional legal requirement is that of Israel. ${ }^{34}$ However, an examination of past practice will at once reveal that this criterion has never been interpreted very strictly. For example, Albania was admitted to membership in the League of Nations even though her frontiers had not yet been delimited. ${ }^{35}$ It would therefore seem that this traditional criterion of statehood has been treated as of importance in United Nations practice, and that, given its traditional liberal interpretation, it has always been properly applied.

\section{Stable and Effective Government}

The third of the traditional legal criteria of statehood has given rise to considerable and varied controversy. While the question of the existence of stable and effective government has inevitably become linked to some extent to the question of recognition of governments, we are here concerned not with recognition per se, but with recognition as it throws light upon the existence of a state.

The continuing relevance of this criterion may be seen in the applications for membership of the Republic of Korea and the Democratic Republic of Korea. The United States and China have consistently maintained that the government of South Korea is the only lawful government, being elected by the people and exercising effective

to the applications of the divided states of North and South Korea and North and South Vietnam. The Afghanistan representative refused to vote for the admission of Pakistan because his government did not recognize the northwest frontier as a part of Pakistan. GAOR 2d Sess., Plenary 313-14 (A/C.1/188) (1947).

$34 \mathrm{By}$ the time Israel's application came up for final consideration-in March 1949-all the members of the Security Council, with the exception of Egypt, had recognized Israel, as had more than two-thirds of the nations in the General Assembly. Yet Israel's boundaries remained undefined. It may also be mentioned that the boundaries of Yemen-both at the time of her admission and to the present dateare far from clear. And the Republic of the Congo (Leopoldville) was admitted to membership at the 15th session of the Assembly, although a part of the area which was claimed by the Congo was declared by $M$. Tshombe to have seceded and to comprise the separate state of Katanga.

35 League of Nations OFf. J. 1st Ass. 651 (1920). This problem was examined by the Permanent Court of International Justice in the Monastery at St. Naoum Case, P.C.I.J., ser. B, No. 9, at 9-10 (1924), which found nothing amiss in the fact that the Great Powers had recognized Albania as a sovereign and independent state in spite of the fact that the complete fixing of its frontiers had been prevented by World War I. See also Deutsche Continental Gas-Gesellschaft v. Polish State, [1929-30] Ann. Dig. 11 (No. 5) (1929). The tribunal said: "In order to say that a state exists . . . it is enough that [its] . . . territory has a sufficient consistency even though its borders have not yet been accurately delimited ...." Id. at 15 . It is pointed out in LAUTERPACHT, RECOGNITION IN INTERNATIONAL LAw 30 (1947), that most of the new states which arose after World War I were recognized de facto or de jure before their frontiers were finally laid down in treaties. However, when the doubts as to the future frontiers were of a serious nature, statehood became in doubt. Thus, when in 1919 Estonia and Latvia were recognized by the Allied Powers, no recognition was granted to Lithuania on the express ground that owing to the Vilna dispute, her frontiers were not yet fixed. 
control over that part of Korea which the United Nations Commission was able to observe and in which the great majority of the Korean people live. $^{36}$ Certainly this government was acknowledged by the General Assembly as the only government in Korea by its resolution of December 12, 1948. ${ }^{37}$ The Soviet Union, on the other hand, has argued that the South Korean Government is a puppet government, created by illegal action of the United Nations. ${ }^{38}$ Two points become apparent: first, that by and large there has been a tendency among members to interpret this legal criterion to mean democratic, rather than purely effective, government; and second, that the requirement of the existence of a government as a prerequisite to statehood at times comes very near, and in part overlaps, the requirement of independence, which will be discussed below. Thus, as to the applications for membership of the Republic of Vietnam and of the Democratic Republic of Vietnam, the representative of France contended that "the so-called Democratic Republic of Vietnam has none of the attributes which confer international status on a State . . . [and] represents nothing but a political faction." 39 Similariy, when the application of Israel was under discussion, the Syrian representative questioned not only the legal, but also the moral, existence of that country's provisional government: "What is the Provisional Government of Israel? Who elected it? Does it rest upon the people? There have been no elections so far. The Government has nothing to substantiate it. It cannot be recognized as a democratic Government. . . . We cannot consider such a Government as a Government with adequate right to claim admission to membership in the United Nations." 40

The fairly distinct pattern of consistent adherence to the requirement of a stable and effective government in United Nations practice

36 SCOR 4th year, 409th meeting 14-15 (S/1238) (1949); SCOR 4th year, 410th meeting 10 (S/1238) (1949); SCOR 4th year, 423d meeting 2 (S/1238) (1949).

37 See GAOR 3d Sess., 187th meeting Resolutions No. 195(III) (A/788) (1948).

38 SCOR 4th year, 410th meeting 8, 9, 15 (S/PV.410) (1949); SCOR 7th year, 599th meeting 25 (S/PV.599) (1952); GAOR 7th Sess., Ad Hoc Pol. Comm. $272(\mathrm{~A} / 2208)(1952)$.

39 SCOR 7th year, 603d meeting 12 (S/2773) (1952). Compare the reply of the Russian delegate that "the Democratic Republic of Vietnam exists . . . its army, parliament and government exist and, which is most important and fundamental . . . its people exist." Id. at 15. "Is it not convincing argument in proof of the existence of the Democratic Republic of Vietnam that French ruling circles have now been waging an obdurate struggle for over five years against that Republic -. ?" Id. at 14-15.

40 SCOR 3d year, 385th meeting 4-5 (S/PV.385) (1948). Compare the comment of the United States representative that the government of Israel was a functioning political entity with firmly established governmental institutions exercising effective internal administration. SCOR 3d year, 383d meeting 12 (S/1093) (1948). Other examples may be found, such as the observation of the Australian delegate upon the application of Ceylon that that country had "a democratic government which exercises full atthority over the territory and population." GAOR $3 d$ Sess., pt. 1, Ad Hoc Pol. Comm. 132 (A/617) (1948). 
has been blurred by the recent admission of the Republic of the Congo (Leopoldville) to the world organization. ${ }^{41}$ The recommendation of the Security Council that the Congo be admitted to membership occurred at a time when there was no doubt as to the existence of a legal and effective government. ${ }^{42}$ When, on September 19, 1960, the General Assembly voted to admit the Congo to the United Nations, ${ }^{43}$ political considerations made it impossible for either the East or the West to oppose the action, although the fact that the Assembly was unable or unwilling to choose among the warring Congolese factions to seat a representative of the new nation suggests that there were considerable grounds to doubt the existence of a government that was either stable or effective at this crucial date. Certainly subsequent events, while not controlling as to the validity of the original action, confirm these earlier grounds for doubt.

Some mention of the position of China should be made at this point. That nation was admitted as a signatory member of the United Nations at a time when there was no doubt that it had an effective government. However, since 1949 there has been open dissension as to whether the effective government of China is still the Nationalist government or is that of Mao Tse-tung, whether there are now two states of China, and whether a change should be made in the representation of China in the United Nations. ${ }^{44}$ I would suggest that the issue is properly one of representation, and that the all too frequently made contention that the case of China in the United Nations represents a departure from the legal requirement of an effective government is fallacious. It is perhaps worth emphasizing that the necessity of statehood, mentioned in Article 4, is, like the requirement that an applicant be "peace-loving," relevant to the claim of admission, and not to continued participation. Thus Article 6, which deals with expulsion from the Organization, does not give as a ground a lapse in effective government or a change in effective government. Such issues are more properly dealt with in terms of changes in the representatives of states already admitted. ${ }^{45}$

41 See GAOR 15th Sess., Supp. No. 16, at 64 (A/4684) (1960).

42 U.N. Doc. No. S/4377 (1960). (1960).

43 GAOR 4th Emer. Spec. Sess., 863d meeting, Plenary 102 (A/L.292/r.1)

44 See, e.g., LaUterpacht, Borchard, Wright \& Morrison, Legal Aspects in the FAR EAstern Problem 115 (1941); Wright, The Chinese Recognition Problem, 49 AM. J. INT'L L. 320, 329 (1955).

$45 \mathrm{It}$ is of interest that since the Hungarian uprising of 1956 the credentials of the Hungarian representatives at the United Nations have not been approved by the credentials committee. However, the representatives have been admitted to full participation in the work of the organization, in spite of this gesture. Unlike the case of China, there was-save for a brief spell-no rival government in Hungary claiming to be the effective government of that state. 
In summary, it may be said that, apart from the aberration in the case of the Congo, the long-established criterion of effective government as a prerequisite to statehood has been fully conceded and adhered to in United Nations practice; and that there has been a tendency on the part of both East and West to give at least lip service to the idea that such government should be the seat not only of effective, but also of formal, authority, in that it should be selected by the free choice of the people concerned. The issue of how much of the territory must be controlled by a government for it to be effective remains incapable of precise answer; but the suggestion that an attitude of caution be maintained towards a government engaged in civil war with a rival national government seems sound. ${ }^{46}$

\section{Independence}

Traditional international law has long demanded that before an entity can be acknowledged as a state, it must possess independence and sovereignty. The problem of the degree of compliance necessary is manifestly even more acute in relation to this criterion than in relation to those of fixed frontiers and stable government. A wealth of material arising from the practice of the United Nations is available and reveals much disagreement in the organization itself both as to what constitute the legal requirements of independence and as to when in fact these requirements have been met.

It is difficult to gauge the degree to which the political organs of the United Nations have followed this criterion, since not only are the many cases on this point open to varying interpretations, but the traditional law on the subject is itself less precise than one might hope. The writings of jurists reveal disagreement centered on two main questions: Can a dependent entity be a state in international law? At what point do restrictions upon sovereignty cause a loss of independence? These questions are most meaningfully discussed in the context of the claims in which they were raised, and here we are concerned with claims for comprehensive participation in the United Nations.

It would seem that the concept of independence is an indispensable element in the notion of statehood under international law when the term "state" is used for a claim to comprehensive participation. ${ }^{47}$

46 See Rudzinski, supra note 26 , at 173 , where it is suggested that from this point of view the early endorsement by the General Assembly of the application for membership of the Republic of Korea (though it proved abortive in the circumstances) in Resolution 296 (IV) was rather premature.

47 "International law governs relations between independent States." Case of the S.S. "Lotus," P.C.I.J., ser. A, No. 10, at 18 (1927). Its aim is "to regulate the relations between those co-existing independent communities." Ibid. Cf. id. at 34 (Loder, J., dissenting): "The family of nations consists of a collection of different sovereign and independent States." 
The Report of the International Committee of Jurists investigating the Aaland Islands Case in $1920^{48}$ is instructive. After recalling the conditions of revolution and disorder which had prevailed in Finland at the time, it stated:

It is therefore difficult to say at what exact date the Finnish Republic in the legal sense of the term actually became a definitely constituted sovereign state. This certainly did not take place until a stable political organization had been created, and until the public authorities had become strong enough to assert themselves throughout the territories of the state without the assistance of foreign troops. ${ }^{48}$

A similar emphasis on the notion of independence is to be found in the Customs Union case, ${ }^{50}$ which contains the celebrated definition of independence by Judge Anzilotti: "[Independence] . . . may also be described as sovereignty (suprema potestas), or external sovereignty, by which is meant that the State has over it no other authority than that of international law. The conception of independence, regarded as the normal characteristic of States as subjects of international law, cannot be better defined than by comparing it with the [class of] . . . "dependent states." "51 This definition requires the presence of two elements: the "separateness of the state and its direct subordination to international law. ${ }^{52}$

Thus stated, a problem immediately poses itself: In deciding whether an entity is indeed independent, does one look merely to the formal arrangements relevant to its independence, or does one "look behind" the formal arrangements to the effective facts? In other words, is "actual independence" as much a condition of statehood as "legal independence"? I would say that it is on the assumption that any appraisal of criteria which is to be of legal significance must go beyond mere form to substance. ${ }^{53}$ There are obviously great difficulties involved in implementing this choice-particularly in obtaining and handling material to determine "actual" independence. However, if a legal evaluation of actual independence proves impossible, then

48 League of Nations Off. J., Spec. Supp. No. 3, at 3 (1920).

49 Id. at 9.

50 Customs Régime Between Germany and Austria, P.C.I.J., ser. A/B, No. 41 (1931).

$51 \mathrm{Id}$. at 57.

52 A comprehensive and most useful discussion of this twofold approach to the concept of independence is to be found in MAREK, IDENTITY AND CoNTINUITY oF States in Public International Law 166-80 (1954).

53 Authority for the view that actual independence is relevant may be found in LAUTERPACHT, RECOGNITION IN INTERNATIONAL LAW 46-51 (1947). See also 1 SCEWARzENBERGER, INTERNATtonat LAW 58 (2d ed. 1949), where it is asserted that at a certain point it becomes sheer formalism to argue that a restriction on the exercise of sovereign rights accepted by a treaty cannot be considered as an infringement of sovereignty. 
political motivations must be channelled into useful and desirable paths to help assess the situation. ${ }^{54}$

It is apparent that absolute independence is impossible in present day society, that states are becoming increasingly interdependent in spheres which at one time would have been regarded as solely within the internal domain..$^{55}$ The question of the extent to which independence or sovereignty ${ }^{56}$ may be delegated or ceded to another entity without resultant loss of statehood has never had a simple answer. One can only ask: At what stage has a state consented to such limitations of its independence that it is "shorn of the last vestige of power" and that "a ghost of a hollow sovereignty cannot be permitted to obscure the realities of this situation"? ${ }^{57}$ It would seem that the sovereignty of a state goes so far as to authorize it to resign sovereignty and thus "commit suicide" under international law, as when a state enters into a federation and loses its international personality. To discover whether it was "suicide" or "murder," 59 it is necessary to look behind formalism to the facts.

An examination of United Nations practice with regard to the traditional requirement of independence may best be carried out in regard to certain legal arguments which have arisen concerning that concept.

\section{Mode of Establishment and Maintenance}

Both the Eastern and Western blocs in the United Nations have consistently recognized the relevance of actual and not mere legal independence, although they have differed in their interpretation of the facts in given cases. Both the definitions of independence cited above and the emphasis in the Charter upon the rights of peoples

54 Some suggestions of the values which should be sought in any such ultimate political solution are made at the end of this Article.

55 See, e.g., Jessup, The Equality of States as Dogma and Reality, 60 Por. Scr. Q. 527 (1945). On forms of contemporary economic dependence, see generally HawTREx, Economic Aspects of SOVEREIGNTy (2d ed. 1952).

56 It should be stated that in this Article these terms are being used interchangeably, although the author is well aware that it has been suggested that the two terms represent distinct sets of facts. Van Kleffens, Sovereignty in International Lavo, 82 RECEUIL DES COURS 89 (1953), contends that the term "independence" presupposes the presence of at least two states, whereas "sovereignty" is not so conditioned, thus making the latter an absolute term, the former a relative one. Compare dictum in the Island of Palmas Case (The Netherlands v. United States), 2 U.N. Rep. Int'1 Arb. Awards 829, 838 (1928), that "sovereignty in the relations between States signifies independence." In Customs Régime Between Germany and Austria, P.C.I.J., ser. A/B, No. 41 (1931), the Permanent Court appeared to treat as synonymous the characteristics of sovereignty and independence.

57 Lighthouses in Crete and Samoa Case, P.C.I.J., ser. A/B, No. 71, at 127 (1937) (Hudson, J.).

58 See St. Korowicz, Introduction to International Law 67 (1959).

59 It is suggested, for example, that the ostensible self-annihilation of Lithuania, Estonia, and Latvia, in 1940 was in fact provoked by pressure from without. 
to self-determination make it clear that independence, though formally present, may actually be lacking if the so-called state is created or maintained by an external power against the will of its people. Such cases go beyond the line of that necessary dependence on other states which is part of the complexity of international relations. ${ }^{60}$

In spite of repeated affirmations of these principles by both East and West, certain states have been admitted to the United Nations whose true independence may be questioned. However, this does not indicate the rejection of actual independence as a valid criterion of statehood; rather, it illustrates the difficulty of ascertaining the facts needed to make the required judgment. ${ }^{61}$

The case law of the United Nations abounds in examples of controversies under this head. The application of the Republic of Korea for membership met with the opposition of the Communist states, the U.S.S.R. claiming that it was in reality nothing more than a puppet state imposed upon the Korean people by foreign occupation authorities with the assistance of members of the United Nations Temporary Commission on Korea. ${ }^{62}$ Similarly, when the application of South Vietnam was discussed, the Soviet delegate stated that "that colonial state . - was only being maintained at the sacrifice of the people of Vietnam by the Franco-American aggressors." ${ }^{33}$ With respect to Laos and Cambodia, the Soviet representative held that the mere fact that an official statement by a French Minister was needed for the submission of their applications to the United Nations revealed that they were puppet states. ${ }^{64}$

60 Thus Judge Anzilotti in the Customs Régime Between Austria and Germany, P.C.I.J. ser. A/B, No. 41 , at 58, commented "that the legal conception of independence has nothing to do . . . with the numerous and constantly increasing states of de facto dependence which characterize the relation of one country to other countries."

61 Past practice has shown the necessity of this criterion of statehood-as in the cases of the "puppet states" of Slovakia, Croatia, and Manchukuo. Thus, following her attack on China in 1931, Japan refrained from a straightforward annexation of Manchuria, instead setting up a state which served all the purposes of annexation in everything but name. The formal aspects of Manchukuo's alleged statehood were carefully preserved, causing such distinguished jurists as Professor Cavaré to assert the statehood of Manchukro. See Cavaré, La Reconnaissance de l'état et le Mandchoukouo, 42 RevUe GÉNérale de Droit International Public 5, 32 (1935). However, the Report of the League of Nations Commission gives little support to this attitude; rather, it upholds the viewpoint that formal criteria are not enough-that an examination of the facts is still necessary. See REPORT OF COMM'N OF ENQUIRY 97 (League of Nations Publ. No. 1932.VII.A.12). See also the resolution adopted by the League Assembly on February 24, 1933, League of Nations Ofr. J., Spec. Supp. 112, at 75-76 (1933). For a most useful commentary on the problem of puppet states, see generally MAREK, op. cit. supra note 52 , at $112-20$.

62 SCOR 4th year, 423 d meeting 7 (S/1281) (1949).

e3 SCOR 7th year, 603d meeting 4-9 (S/PV.603) (1952).

64 Id. at 2 . It should be added that during consideration of these applications by the Ad Hoc Political Committee, the representatives of Burma, India, Indonesia, and the Philippines all abstained from the draft declarations in favor of admission, because they were doubtful of the status of the applicants. GAOR 7th Sess., Ad Hoc Pol. Comm. 318 (A/AC.61/L.38), (A/AC.61/L.39), (A/AC.61/L.40) (1952). 
The relevance of the mode of establishment of a state to the criterion of independence is well illustrated by Mongolia's application for admission. The application has been before the United Nations since its second session, and efforts by the Soviet Union to secure its acceptance were only temporarily suspended in the last few years. The U.S.S.R. claimed that the Mongolians had attained their independence by democratic means, having voted for independence in 1945, and that this plebiscite had been recognized by Mongolia's two immediate neighbors, China and the Soviet Union. ${ }^{65}$ Nevertheless, the majority of the members of the Committee on Admissions thought that the information available was not enough to show that Mongolia was in fact an independent state. ${ }^{68}$ However, by the tenth session of the Security Council, in 1955, it began to look as if an arrangement would be made for the approval of most of the applications which had been pending for the past six years. The Cold War was thawing and a compromise formula for the admission of states backed by East and West-with the exception of the divided states-had been reached. ${ }^{67}$ The United States stopped pressing the point that Mongolia lacked the requisite independence, ${ }^{68}$ and for a while it looked as if the application of Mongolia might go through successfully together with the other seventeen. However, subsequent to China's recognition of Mongolia, border disputes had arisen between the two nations, changing China's initial support into opposition. ${ }^{69}$ Furthermore, in a sixtymember General Assembly, the United States had clear power to prevent the ouster of Nationalist China, whereas the admission of eighteen new members would possibly change the balance on this issue. Therefore, Nationalist China, claiming that the so-called "package deal" was unconstitutional and that Mongolia failed to fulfill the requirements of Article 4, vetoed the application, with the consequence that the Soviet Union vetoed the application of Japan. ${ }^{70}$

65 SCOR 1st year, 2d ser., Supp. No. 4, at 65 (S/95) (1946).

66 See SCOR 2d year, Spec. Supp. No. 3, at 13 (S/95) (1947). See generally Condittons to ADMission of a State to MeMrbership in the United Nations Case-Pleadings, Oral Arguments, and Documents 42 (I.C.J. 1948) (Dr. Kerno), which contains a useful summary of the fortunes of this and other applications.

67 The history of this period has been amply recorded elsewhere. See, e.g., Gross, Progress Tozeards Universality of Membership in the United Nations, 50 ANs. J. INT'L L. 791 (1956) ; Robinson, Metamorphosis of the United Nations, 99 RECEUII. DEs Cours 497, 503-13 (1958); Rudzinski, Admission of New Members, 1952 INT'L CoNc. 143.

${ }^{68}$ See SCOR 10th year, 701st meeting 18 (S/PV.701) (1955).

69 In 1947 Mongolian troops invaded China to a depth of 100 kilometers. This matter was raised by the Chinese representative as evidence that Mongolia was not "peace-loving." SCOR 10th year, 703d meeting 11 (S/PV.703) (1955).

${ }^{70}$ SCOR 10th year, 704th meeting 11, 14 (S/PV.704) (1955). See also SCOR 10th year, 706th meeting 1-22 (S/PV.706/r.1) (1955). 
The political overtones in the case of Mongolia are so strong that little or no conclusive evidence can be obtained on the relevance of the issue of independence as evidenced by the mode of establishment and maintenance of the state. It is of significance that prior to the plebiscite in 1945, the Soviet Union had acknowledged China's sovereignty over Outer Mongolia; the recognition by China of the full sovereignty of the Mongolian People's Republic subsequent to the plebiscite supplied at least prima facie evidence of the independent status of that country. ${ }^{71}$ The evidence examined by the Security Council Committee on Admissions revealed an independence that would appear to have been at least as great as that of several nations which were acknowledged members of the United Nations. ${ }^{72}$ From any point of view, the case study of Mongolia can only be termed unsatisfactory; if it is used as proof that one looks only to formal independence and not to actual independence, then it is difficult to see why the application was rejected, and even more difficult to understand the great amount of time and effort expended on assessing facts as to actual independence. If one looks to actual independence, there would still appear to have been sufficient grounds for the admission of Mongolia. The best conclusion that can be reached is that the political pressure being exercised at the time caused a deviation from legal norms on the issue of statehood, despite the availability of a better political alternative provided by the fact that Article 4(1) allows a negative vote to be cast on the grounds that the applicant is not "peace-loving."

An interesting case in which the actual independence of an applicant was challenged on the grounds of an irregular mode of establishment was that of Transjordan. The Polish delegation doubted the sovereign independence of that nation, noting that Transjordan had been a mandate and that the only way of bringing a mandate to a close was by conformity with conditions which the League of Nations laid down. ${ }^{73}$ The Polish Representative was of opinion that, in view of the demise of the League, Article 77 of the Charter ${ }^{74}$ now applied,

71 See Friters, Outer Mongolia and Its International Position 286-87 (1949). China, torn by her own civil wars, had ceased to be able to exercise any effective pressure on Mongolia, and a face-saving formula was found by an exchange of notes on August 14, 1945, in which the Chinese Government agreed to recognize the independence of Outer Mongolia within its existing boundaries if a plebiscite confirmed the desire for this.

${ }^{2}$ See SCOR 1st year, 2d ser., Supp. No. 4, at 64-67 (S/95) (1946); SCOR 2d year, Spec. Supp. No. 3, at 8-13 (S/95) (1947).

73 SCOR 1st year, 2d ser., Supp. No. 4, at 70-71 (S/133) (1946); id. apps. 15, 17, at 133-37, 140-43. See generally Conditions of AdMission of a STATE to MEMberseip in the United Nations Case-Pleadings, Oral Arguanents and DocUMENTS 50 (I.C.J. 1948) (Dr. Kerno).

74 Art. 77, para. 1: "The trusteeship system shall apply to such territories in the following categories as may be placed thereunder by means of trusteeship agreements: (a) Territories now held under mandate . . . ." 
and that the formal agreement of the General Assembly was required to end the mandate. A resolution did exist stating that the Assembly "welcomes" the intention of the United Kingdom to establish Transjordanian independence, ${ }^{75}$ but the Polish representative contended that this was still a long way from recognizing a mandate as a sovereign state. The United Kingdom, on the other hand, insisted that Article 77 was not mandatory, ${ }^{76}$ that as it had been made clear before the General Assembly that Transjordan was to become a sovereign independent state, no question of placing it under trusteeship arose, and that the General Assembly resolution clearly endorsed the decision not to place it under trusteeship. In the outcome, the arguments of the United Kingdom prevailed, and Jordan was admitted along with sixteen other nations, by unanimous recommendation of the Security Council, in December 1955-yet another instance of the thaw in the cold war causing the dropping of previously used legal arguments. However, the fact remains that an objective assessment would have revealed an adequate independence of the applicant, and runs counter to any argument that the so-called "package deal" allowed the admission of entities which were not truly states.

\section{Defense Arrangements with Former Colonial Powers}

This head is obviously closely related to the preceding one. It has been suggested on various occasions when formal independence has been granted that actual independence does not exist due to military arrangements which have been made with the former colonial power which give it an effective control so great that the independence of the new "state" is in name only. The applications for membership of both Ceylon and Transjordan met with this argument. The treaty concluded in London on March 22, 1946, between the United Kingdom and Transjordan, ${ }^{77}$ arranging for the independence of the latter, contained stipulations allowing the stationing of British armed forces in Transjordan, storage of supplies and ammunition, facilities for the training of armed forces, financial assistance to cover the cost of the Transjordan army and the supervision of such funds. Both the

75 GAOR 1st Sess., pt. 1, Resolutions Adopted Jan. 10-Feb. 14, 1946, No. 11, at 13 (1946).

76 SCOR 1st year, 2d ser., Supp. No. 4, App. 16, at 137-40 (S/133) (1946). The problem of whether Article 77 is mandatory has been fully discussed elsewhere. See generally Hall, Trusteeship System, 24 BrIT. YB. INT'L L. 164 (1947); Parry, The Legal Nature of the Trusteeship Agreements, 27 BRIT. YB. INT'L L. 164 (1950); Sayre, Legal Problems Arising From the United Nations Trusteeship System, 42 AM. J. INT'L L. 263 (1948). The opinion of the International Court of Justice in the International Status of South-West Africa Case, [1950] I.C.J. Rep. 128, is also instructive.

776 U.N.T.S. 143. 
U.S.S.R. and Poland claimed that these arrangements impaired the real independence of Transjordan. ${ }^{78}$ Similar objections with regard to Ceylon ${ }^{79}$ were probably less justified; the unique position of independent states remaining within the British Commonwealth of Nations does much to explain mutual defense arrangements made between Ceylon and the United Kingdom when Ceylon became independent. ${ }^{80}$ In neither case did the objections prevent the ultimate admission of the applicant.

The status of the newly independent countries would bear examination in the light of these considerations. Sixteen new states have been admitted to membership in the United Nations since the beginning of 1960. Fifteen of these are in Africa.

Nigeria, formerly a British protectorate, has no major military commitments to the United Kingdom. ${ }^{81}$ Discussions which took place between the government-elect of Nigeria and Her Majesty's Government in Britain resulted in an understanding that a mutual defense agreement would be signed "some time after independence." 82 No doubt can exist as to Nigeria's fulfillment of the requirements of independence under this head. Equal freedom from defense arrangements with the former colonial power exists in the case of Somalia, ${ }^{83}$ which to date has incurred no such obligations. ${ }^{84}$

The position with regard to the former French colonies in Africa is more complex. Both Togo and Cameroon have achieved complete independence. Neither is a member of the French Community and neither has signed a treaty of defense with France or is expected to do so. The Malagasy Republic (formerly Madagascar), on the other hand, is under treaty obligation to France ${ }^{85}$ to provide mutual aid and assistance in case of attack, and has placed the base of Diégo-Suarez at the disposal of the armed forces of the French Community. ${ }^{86}$ The Federation of Mali, comprising Sudan and Senegal, signed a treaty

78 SCOR 1st year, 2d ser., Supp. No. 4, at 136 (S/101) (1946); GAOR 2d Sess., Plenary 1044-53 (A/471) (1947).

79 SCOR 3d year, 351st meeting 11-12 (S/820) (1948).

80 See, e.g., Bailey, Ceylon's New Status, 17 Far EASTERN Survey 251-54 (1948); Jennings, Dominion of Ceylon, 22 Pacrfic Afratrs 21-33 (1949).

81 See Nigeria Independence Act, 1960, 8 \& 9 Eliz. 2, c. 55.

826 Comaronwealth Survey 501 (1960). Such an agreement has now been concluded. CMo. No. 1212 (1960).

83 Compromising the territories that were formerly British Somaliland and Italian Somalia. The United Kingdom and Italy, respectively, held them as administering authorities under United Nations trusteeship.

84 Agreements and Exchanges of Letters between the Government of the United Kingdom and Somalia, 1960. See also Somaliland Protectorate Constitutional Conference, Report, CaD. No. 1044 (1960).

85 Treaty of April 13, 1960, Bordereau Collectif No. 348/ct.

${ }^{86} \mathrm{Id}$. art. 1(b) : "Elle [France] aura la disposition de la base stratégique de Diégo-Suarez et d'installation militaires en en autres villes." 
with France on April 13, 1960. ${ }^{87}$ This likewise provided for mutual aid and assistance, and ceded to France the bases of Cap-Vert (DakarThiès), Saint-Louis, Kati, Bamako, Gar, and Tessalit. ${ }^{88}$ However, Senegal withdrew from the federation and was recognized as a separate independent state by France on September 11, $1960 .{ }^{89}$ On September 22, Sudan, renamed the Republic of Mali, also achieved separate statehood. ${ }^{90}$ Mali has withdrawn, at least temporarily, from the French Community and has declared the accords with France to be null and void. ${ }^{91}$ Senegal, remaining within the Community, apparently continues to regard itself as bound by the agreements with Paris, and hence the cession of the base of Cap-Vert remains good. ${ }^{92}$ The Ivory Coast, Republic of the Upper Volta, Niger Republic, and Dohomey Republic had signed no agreements with France at the date of their admission to the United Nations, although such agreements are expected to be signed early in $1961 .^{93}$ As for Chad, Gabon, the Republic of the Congo (Brazzaville), and the.Central African Republic, the agreements which they signed as members of the French Community ${ }^{94}$ provided neither for territorial reservations to France, nor for mutual aid and assistance.

None of these states has committed itself to defense arrangements which can truly give rise to doubts as to its independence. Treaties of mutual defense and assistance are commonplace, and the granting of bases to foreign troops is unexceptionable-especially within the framework of a "community" which in many ways resembles that of the British Commonwealth. Any other interpretation would be unjustified; certainly it would be a sad position for international law to be caught in if newly independent states had to prove their independence by total and complete rupture from their former administrators.

87 Bordereau Collectif No. 348/ct.

88 Accord de Cooperation en Matière de Défense, Bordereau Collectif No. 348/ct. Annex 111. The French Army is to have free use, to military ends, of the facilities ("éléments constitutifs") of these bases. The distinction between the "ceding" of these bases and "granting of disposition" over those of the Malagasy Republic is not entirely clear.

89 By virtue of a communique from the office of Premier Debré. Le Monde, Sept. 13,1960 , p. 7 , cols. $1 \& 2$.

${ }^{90}$ Le Monde, Sept. 23, 1960, p. 1, cols. 3 \& 4 .

01 This position has apparently been accepted by France. See note 92 infra.

92 It is uncertain at the present time whether new accords will be signed between France and Senegal. I am grateful for this information and for that contained in note 91 supra to M. Guy de Crommines, Counsellor on African Affairs, of the French Embassy in Washington. Further discussion as to the present status of this treaty is more properly a question of state succession, and as such is beyond the scope of this Article.

93 N.Y. Times, March 8, 1961, p. 3, col. 6.

94 Treaties of April 13, 1960, Bordereau Collectif No. 348/ct. 
The position with regard to Cyprus is more ambiguous. ${ }^{95}$ Military facilities reserved to the United Kingdom are both extensive and farreaching. The bases of Akrotiri and Dhekelia are reserved to British sovereignty..$^{96}$ Further, other sites may be used "without restriction or interference," ${ }^{\theta 7}$ and extensive rights of control exist over Nicosia airfield ${ }^{98}$ and certain other military facilities. ${ }^{99}$ Unlike Senegal and the Malagasy Republic, Cyprus has no benefit of restriction as to the use to which the United Kingdom may put these bases. Certainly this case would seem to come very close to the borderline of lack of true independence, ${ }^{100}$ yet no voice of protest was raised against the admission of Cyprus.

\section{Inadequate Size and Resources}

The question is also asked, usually in relation to the "diminutive state": At what point do limitations upon size or resources of a state impair its true independence? It is noteworthy that no "diminutive state" has ever applied for comprehensive membership in the United Nations; hence there is no United Nations practice directly on point. ${ }^{101}$ Moreover, when discussing limitations on size and resources it becomes difficult to determine whether they more directly affect statehood per se or ability to carry out the obligations of the Charter, as required of it by Article $4 .{ }^{102}$ This is especially true if one regards "statehood" and "independence" as normatively ambiguous terms capable of precise definition only when tied to specific claims. However, ability and willingness by itself will not suffice for the admission of an entity which is not truly independent; and both reasons have to be offered for the nonappearance of such entities as San Marino, Monaco, Andorra, and Liechtenstein upon the list of members. ${ }^{103}$

95 See Draft Constitution of the Republic of Cyprus, in Secretary of State for the Colonies, Cyprus, CaD. No. 1093, app. D (1960).

96 Draft Treaty Concerning the Establishment of the Republic of Cyprus, art. 1, in Secretary of State for the Colonies, supra note 95, app. A, at 13.

97 There are twenty-five, of which thirteen are to be given back to Cyprus "as soon as practicable." Id. ann. B, pt. II, §1(2), at 21 .

$98 \mathrm{Id}$. $\$ 4$, at 23 . Ibid.

89 Including fifteen camps, buildings, and installations, and right of access thereto.

100 See 196 The Economrst 250 (1960): "Few new states have had the conditions of their independence so explicitly and elaborately defined, or have been thrust so quickly into a rigid mould which they are debarred from changing. Fewer still have been forced to allow a former ruling power to retain a sovereign toehold on their territory, as well as other extensive rights."

101 Although, as will be seen below, this question has arisen with claims to limited participation in United Nations affairs, especially with reference to membership in the specialized agencies.

102 Rudzinski, supra note 67 , at $146-47$.

$103 \mathrm{It}$ is of interest that Liechtenstein was denied admission to the League of Nations in 1920 on the grounds that "this state does not appear to be in a position 
The relationship of these two factors is underlined by the admission to the United Nations of several new states whose physical and economic resources must be termed "inadequate." However, by virtue of agreements with their former colonial powers, economic aid is guaranteed. While such agreements do not infringe upon the independence of these states-although all economic dependence implies a certain degree of political dependence, the choice of sources of aid available in Africa prevents the dependence on the former colonial power from being too great - they do help to guarantee, inter alia, that the nations concerned will be able to carry out their obligations under the Charter.

\section{Limitations in Conducting Foreign Relations}

The traditional literature of international law was much concerned with the possibility of "dependent states," particularly in cases where one state had the power to conduct foreign relations for another. ${ }^{\mathbf{1 0 4}}$ It might be suggested that every time the United Nations has allowed an entity which lacks independence in foreign relations to participate in

to carry out all the international obligations imposed by the Covenant." LEAGUE of Nations OfF. J. 1st Ass. 667 (1920). The report made by the Fifth Committee to the League Assembly commented, "The Principality of Liechtenstein possesses a stable government and fixed frontiers. There can be no doubt that juridically the Principality of Liechtenstein is a sovereign state, but by reason of her limited area, small population and geographical position, she has chosen to depute to others some of the attributes of sovereignty. For instance, she has contracted with other Powers for the control of her customs, and administration of her Posts, Telegraphs and Telephone Services, for the diplomatic representation of her subjects in foreign countries, other than Switzerland and Austria, and for final decisions in certain judicial cases." Luxembourg, however, was admitted without the question of size being raised. Rudzinski, supra note 67 , at 173 . Iiechtenstein has not applied for membership in the United Nations.

104 International law has developed beyond and away from the old concept that only states may be its subjects. See Schwarzenberger, The Protection of Human Rights in British State Practice, 1 CURRent Legal Problems 153 (1948). See also Dunn, The International Rights of Individuals, 1941 Proc. AM. Soc'y INT'L L. 14; Lauterpacht, The Subjects of the Laze of Nations, 63 L.Q. Rev. 438 (1947). Nevertheless, the rejection of a broader phrasing suggested at San Francisco in favor of the term "state" in article 4 of the Charter indicates that this concept may yet rule us from its grave. Curiously enough, article 1 of the League of Nations Covenant expressly permitted the membership not only of states, but of dominions and colonies. Moreover, whereas only states may be parties before the International Court of Justice, STAT. INT'L CT. JUST. art. 34, para. 1, the corresponding provision of the Statute of the Permanent Court of International Justice said that "only states or members of the League of Nations can be parties before the Court," STAT. PERM. INT'L C. JUST. art. 34. (Emphasis added.)

Traditional doctrine and literature upheld the concept of dependent states, though invariably with reservations as to their "exceptional character." Thus, Oppenheim affirmed their existence, but noted that not only are dependent states an anomaly, but the very existence of states without full sovereignty is an anomaly itself. 1 OPPENHETM, INTERNATIONAL LAW 114-16 (6th ed. 1947). The same conclusion is reached by both Hyde and Rolin. 1 Hyde, InTERNATIONAL LAw 22 (2d rev. ed. 1945); Rolin, Les principes de Droit International Public, 77 RECEUIL DES Cours 309,326 . Kelsen stands out as a comparatively lone voice in refuting the idea of a "dependent state." Kelsen, General Theory of LAW aNd State 248-52 (1946). 
some activity open only to states, it has either recognized a "dependent state" or ignored the criterion of statehood. But this argument may be avoided by recognizing that the term "state" has no fixed meaning, but varies in content according to the claim for which it is a relevant consideration. Thus, in considering United Nations practice, the degree of independence required of an entity before it can be called a "state" or be permitted to have an international personality depends on the claim advanced. Where the claim has been for comprehensive participation, the United Nations has required the applicant to maintain a high degree of sovereignty in the conduct of its foreign relations.

It has been suggested that the membership of Luxembourg in the United Nations indicates the existence of a "dependent state," 105 since that nation is universally recognized as a sovereign state, in spite of its abandonment in favor of Belgium of the power to conclude commercial treaties. ${ }^{106}$ However, this example is not conclusive; the delegation of authority by Luxembourg would not warrant the assumption that it is a dependency. ${ }^{107}$ Presumably, in much the same way as the degree of control required to assert successfully rights of prescription and acquisition over a territory depends in part upon the conditions of the territory in question, ${ }^{108}$ the degree of authority exercised by a protecting state necessary to preserve its protectorship depends upon all the circumstances. Thus, in such cases as the British relationship to Muscat or Bahrein, the degree of authority is comparatively slight; but this suffices, since the occasions for international intercourse by those nations are infrequent. ${ }^{109}$ The Permanent Court of International Justice, in the Tunis-Morocco Nationality Decrees Case, also appeared to be of opinion that no hard and fast answer can be given as to where the line which establishes legal dependency is to be drawn. ${ }^{110}$

105 Rolin, supra note 104 , at 326 .

106 Belgique et Luxembourg, Convention éstablissant une Union économique le deux pays, July 25, 1921, 9 L.N.T.S. 224.

107 See St. Korowicz, INTROduction to InTERnational Law 73 (1959), where it is pointed out that the relations of Luxembourg and Belgium are based upon a close economic cooperation; from a legal as well as factual viewpoint, nothing could be stipulated by Belgium which would engage Luxembourg without the clear consent of the latter.

108 See Island of Palmas Case (The Netherlands v. United States), 2 U.N. Rep. Int'l Arb. Awards 829 (1928).

109 Compare the position in Morocco immediately prior to its independence, where the French protectorate used the services of a French official as Minister of Foreign Affairs to the Sultan, while in fact the protected state was largely treated as a separate entity despite the control by the protecting state. See BISHOP, CASES ON INTERNATTONAL LAW 154 (1953).

110 P.C.I.J., ser. B, No. 4, at 27 (1923) (advisory opinion): "In spite of common features possessed by Protectorates under international law, they have individual legal characteristics resulting from the special conditions under which they were created, and the stage of their development." It is of interest that when Denmark and Iceland became members of a union of states by the treaty of Nov. 18, 1918, both remained sovereign states, even though Denmark undertook to manage Iceland's foreign affairs. MCNaIr, LaW of Treaties 434 (1938). 
More specifically, an examination of practice before the General Assembly and Security Council reveals that the lack of ability of a state to conduct its own foreign relations has been regarded as significant, ${ }^{111}$ and in no case of virtually total limitation upon sovereign rights in this regard ${ }^{112}$ has an entity been admitted to membership in the United Nations. Perhaps the only genuinely doubtful case is that of Nepal, which warrants further discussion. Indian influence in Nepal is considerable. Nehru has stated on several occasions that the Himalayas, which lie to the north of Nepal, are India's northern border. The 1950 treaty of peace and friendship between Nepal and India provides that Nepal shall accept Indian aid in case of aggression. ${ }^{113}$ There isnotwithstanding the United States assertion in the Security Council that Nepal has effective control of its external relations ${ }^{114}$ - the closest consultation between the two governments on Nepal's foreign policy. India is kept well informed of Nepalese negotiations with third powers. However, the formal power to conduct foreign affairs lies solely with Nepal, and in practice these arrangements, while obliging her to make information available to the Indian government, have not substantially impaired her freedom to conduct her own foreign relations. ${ }^{115}$

\section{Disabilities Arising from World War II}

It was suggested by certain members of the United Nations that the independence and sovereignty of some of the ex-enemy states had been affected by various factors resulting from the cessation of hos-

111 Thus the Australian delegate thought there was insufficient evidence that Mongolia was able to conduct its own foreign affairs, SCOR 2d year, Spec. Supp. No. 3, at 11 (S/95) (1947); while the U.S.S.R. contended that Japan could only decide foreign policy with instructions from Washington, SCOR 7th year, 602d meeting 14 (S/PV.602/r.1) (1952). On the question of Israel, the United States pointed out that Israel possessed this facet of independence; furthermore, "neither at San Francisco nor subsequently has the United States considered that complete freedom to frame and manage one's own foreign policy was an essential requisite of United Nations membership." SCOR 3d year, 383d meeting 10-12 (S/PV.383) (1948).

112 E.g., Monaco, San Marino, Andorra.

113 July 31, 1950, 2 INDIAN YB. OF INT'L AFFAIRS 316-18 (1953). Rubin, The Sino-Indian Border Disputes, 9 INT'I \& CoMP. L.Q. 96 n.6 (1960), pertinently comments on the apparent incompatibility of Nepalese membership in the United Nations with Nehru's statements of November 27,1959 , to the effect that India will consider any aggression directed against $\mathrm{Nepal}$ as an aggression against India, The Times (London), Nov. 28, 1959, p. 6, col. 1 .

114 SCOR 4th year, 439th meeting 12 (S/PV.439) (1949).

115 Rubin, supra note 113 , at 115 , concludes that the limitations upon Nepal's external affairs in no way suffice to justify any classification of Nepal as less than a full international person. A full analysis of the extent of Indian influence and prior English influence in Nepal may be found in Prudente, Admission to the United Nations as a Diplomatic Instrument, June 1959 (unpublished thesis in Univ. of Southern California Library). See also Levi, Nepal in World Politics, 33 PAcIFic AfFatrs 239 (1957). 
tilities in favor of the Allies. The question arose as to whether a defeated state with whom a peace treaty had not yet been signed and which was occupied by foreign troops retained a sufficient degree of state sovereignty to render it eligible for membership under Article 4. ${ }^{116}$

Both the Soviet Union and Australia initially objected to the admission of Austria ${ }^{117}$ on the grounds that a nation could not be regarded as sovereign or independent when it was occupied by foreign troops and subject to armistice agreements. ${ }^{118}$ The United States, on the other hand, rejected the blind application in all cases of the thesis that restrictions in armistice agreements or other control arrangements were of such a nature as to impair sovereignty. ${ }^{119}$ The United States government felt that this question and that of military occupation should be resolved by the facts in each individual case, and in the present instance, it was argued, the new control agreement ${ }^{120}$ provided that Austria might exercise independent authority.

The same controversy arose over the application for admission of Italy. The United States emphasized that for all practical purposes Italy was not restricted in sovereignty. ${ }^{121}$ The Allied Commission had been terminated on January 31, 1947, and no troops remained in Italy but a token force along the northeast frontier maintained solely to insure a peaceful solution to the border dispute with Austria. ${ }^{122}$ No voices were raised in opposition, since it was in the general interest that Italy, which had been designated the administering authority of the trusteeship of Somaliland, ${ }^{123}$ should become a full member of the United Nations and a member of the Trusteeship Council. ${ }^{124}$

116 This issue is quite distinct from whether a defeated aggressor-state with whom a peace treaty has not yet been signed may be deemed "peace-loving"; and from any rights of adverse vote which may accrue to the Allies under Article 107.

117 Australian opposition to Austrian admission became modified when her government became of the opinion that the delay of the entry into force of the peace treaties was being caused by the unilateral failure of the U.S.S.R to ratify them. However, Australia still maintained that a technical ineligibility for membership persisted, and that the most that could be done under the circumstances was for conditional recommendations to be made to the General Assembly. SCOR 2d year, Spec. Supp. No. 3, app. 14 (S/335) (1947).

118 SCOR $2 d$ year, Spec. Supp. No. 3, apps. 14, 15 (S/403) (1947).

119 SCOR 2d year, 190th meeting 2128 (S/479) (1947).

120 Agreement with the United Kingdom, Union of Soviet Socialist Republics and the French Republic on the Machinery of Control in Austria, June 28, 1946, 15 Dep'T State Bull. 175 (1946).

121 SCOR 2d year, Spec. Supp. No. 3, app. 45 (S/355) (1947).

122 SCOR 2d year, 190th meeting 2120 (S/479) (1947); SCOR 2d year, 203d meeting 2408-09 (S/PV.203/r.1) (1947); SCOR 2d year, Spec. Supp. No. 3, at 20 (S/355) (1947).

123 GAOR 4th Sess., Resolutions No. 289(IV), at 10 (1949).

124 U.N. CFARTER art. 86, para. 1 states that "The Trusteeship Council shall consist of the following members of the United Nations: (a) those members administering trust territories...." (Emphasis added.) 
One of the arguments raised by the Soviet Union against the admission of Japan was that it was still under the control of the occupation forces ${ }^{125}$ and that consideration of the application should be postponed until Japan had concluded normal peace treaties with the U.S.S.R. and the People's Republic of China, which would signify that Japan had again become an independent and sovereign country. ${ }^{\mathbf{1 2 6}}$ However, it would seem that the sovereignty of Japan had never really been compromised. The occupying power-in this case the United States-had allowed the Emperor and his government to remain in Japan during the occupation; there was no reason to suppose that sovereignty had been transferred to the occupying power. ${ }^{127}$

There is no doubt that belligerent occupation without annexation does not cause a transfer of sovereignty. ${ }^{128}$ However, a distinction should be drawn between belligerent occupation stricto sensu during hostilities and occupation after the cessation of hostilities. ${ }^{129}$ I would concur with those authorities ${ }^{130}$ who suggest that occupation in pursuance of armistice terms is governed by the rules contained therein. ${ }^{131}$ Certainly at the time of admission to membership of the ex-enemy states none had had its sovereignty or independence curtailed to any notice-

$125 \mathrm{SCOR} 7$ th year, 601st meeting 9 (S/2754) (1952).

$126 \mathrm{Id}$. at 12 . The United States had concluded a separate peace treaty with Japan on September 8, 1951, [1952] 3 U.S.T. \& O.I.A. 3172. By Article 1(b) "The Allied Powers recognize the full sovereignty of the Japanese people over Japan and its territorial waters." Ibid.

127 See Far Eastern Comm'n, Policy Decision on Basic Post-Surrender Policy for Japan, June 19, 1947, part II, para. 2, 17 Dep't State Bull. 216, 217 (1947), which provided that the Supreme Commander "will exercise his authority through Japanese governmental machines and agencies, including the Emperor . . . ."

128 Hague Rules of LAND Warfare arts. 42-56 (1907).

129 See Stone, Legal Controls of International Conflict 639 (1954). Stone notes that postwar occupation may be either in pursuance of armistice terms or under a peace treaty. An example of the latter is the occupation of the Rhineland after the Treaty of Versailles. See Agreement with Belgium, the British Empire, and Germany with Regard to the Military Occupation of the Territories of the Rhine, June 28, 1919, in 13 Am. J. INT'L L. 404-09 (Supp. 1919). 2 GUGGENHETM, LeHRBUCH DES VÖLKERRECHTS, 926 (1951), adds an additional category of occupation "sui generis" under which he lists the occupation of Germany and Japan.

130 Friedmand, The Allied Milttary Government of Germany (1947); 2 OPPENHEIM \& LAUTERPACHT, INTERNATIONAL LAW 602-04 (8th ed. 1955); STONE, op. cit. supra note 129, at 639; Borton, United States Occupation Policies in Japan Since Surrender, 62 POL. ScI. Q. 250 (1947); Lowenstein, Law and the Legislative Process in Occupied Germany (pts. 1 \& 2), 57 YALE L.J. 722, 994 (1947).

131 It has been suggested that the Declaration of Berlin of June 5, 1945, 12 DEP'T State BULI. 1051 (1945), by which the Major Allied powers assumed supreme authority with respect to Germany, including all the powers possessed by the German government, the high command, and any state, municipal or local government or authority, caused a transfer of sovereignty to take place without the normally necessary annexation. Jennings, Government in Commission, 23 BRIT. YB. INT'I L. 112 (1946); Kelsen, The Legal Status of Germany According to the Declaration of Berlin, 39 AM. J. INT'L L. 518 (1945); Simpson, Berlin: Allied Rights and Responsibilities in the Divided City, 6 INT'L \& CoMP. L.Q. 83 (1957). See also Bottrill, Ex parte Kuechemneister, 1 AM. ECON. Rev. 635 (1946). 
able degree by foreign occupation, subjection to armistice arrangements, or other disabilities arising from the war. ${ }^{132}$

\section{Absence of Diplomatic Relations}

The importance of diplomatic relations has been stressed by both East and West, not merely as a manifestation of ability and willingness to carry out the obligations of the Charter, but in relation to the very existence of independence. Nevertheless, it is difficult to determine whether the majority of members believe that limited diplomatic relations automatically imply a lack of sovereignty and independence or merely provide prima facie evidence of a limitation on an entity's independence. Some claims have also been made that the absence of diplomatic relations-especially relations with certain individual states-in no way reflects upon the status of the country concerned.

China called attention to the fact that Mongolia had very limited diplomatic and consular relations; ${ }^{133}$ and others, while paying lip service to the argument of the United States that this was irrelevant, nevertheless appeared to treat the matter as not entirely insignificant. ${ }^{134}$

Similarly, in the discussion in the Committee on Admissions, the Soviet representative noted that his government attached great significance to the point that Transjordan did not maintain diplomatic relations with Russia. ${ }^{135}$ This was not, he added, mere formal argument, but a "very important reason . . . [touching] upon the qualities of a nation applying for membership." ${ }^{136}$ He conceded that at San Francisco some countries had participated which did not have normal diplomatic relations with the U.S.S.R., but stated that this was due to wartime circumstances which no longer existed..$^{137}$

132 For example, although Syria noted that Austria did not have international recognition of its existence as a sovereign state after the Anschluss, and was not considered a separate enemy state during the war, the United States asserted that Austria had "corporate identity" and pointed out that the Moscow declaration had declared null and void the annexation of Austria by Germany. SCOR 2d year, 154th meeting 1262-63 (S/406) (1947); SCOR 2d year, 190th meeting 2128 (S/506) (1947). 133 SCOR 1st year, 2d ser., Supp. No. 4, at 64-65 (S/95) (1946); GAOR 1st Sess., pt. 2, First Committee 61 (A/C.1/30) (1946).

134 Thus the United Kingdom representative "thought it would be useful to know whether the Mongolian People's Republic would be willing to extend her diplomatic relations to the outer world," SCOR 1st year, $2 d$ ser., Supp. No. 4, at 66 (S/506) (1946), while the Australian delegate was at pains to add as an extra reason for doubting the independence of Mongolia the fact that she only had diplomatic relations with the U.S.S.R., SCOR 2d year, Spec. Supp. No. 3, at 11 (S/95) (1947).

135 SCOR 1st year, 2d ser., 56th meeting 91-92 (S/101) (1946); SCOR 1st year, Supp. No. 4, at 72 (S/101) (1946); SCOR 2d year, Spec. Supp. No. 3, at 14-15 (S/101) (1947).

136 SCOR 2d year, Spec. Supp. No. 3, at 14 (S/101) (1947).

137 SCOR 1st year, 2d ser., 56th meeting 91-92 (S/101) (1946). 
Conversely, both the United States and France cited the existence of diplomatic relations as an indication of the independence of Nepal. ${ }^{138}$ The Nepalese government itself declared that Nepal "has for centuries been an independent sovereign state .... [It] is responsible for its own foreign relations and no power exercises, or for centuries has exercised, any control or authority over it except its own government." 139 The point has been raised on several other occasions. ${ }^{140}$

I would suggest that diplomatic relations between the applicant and any one other state are in no way required to prove independence, but that a marked absence of diplomatic relations with other states may, in the circumstances of the individual case, indicate a limitation on the independence of the nation concerned. Certainly no state has been admitted to full membership in the United Nations after a showing of abnormally limited diplomatic exchanges, although this may be a result of a finding of unwillingness or inability to carry out Charter responsibilities.

\section{Recognition}

Discussions of recognition in United Nations practice have not only stressed unnecessary technicalities, but shown a tendency to deal with a variety of related but distinct topics as one problem. ${ }^{141}$ For the

138 SCOR 4th year, 439th meeting 8, 12 (S/1382) (1949).

139 U.N. Doc. No. S/C.3/16, at 3 (1949). In this regard Prudente, op. cit. supra note 115, notes that for a long time Britain and then India had the only resident ambassadors in Katmandu. Later the United States, France, and others established diplomatic relations. Under a 1955 treaty, Communist China and Nepal agreed to exchange ambassadors. However, at the wish of India, those countries' ambassadors accredited to New Delhi are those accredited to each other. Apparently the Chinese have circumvented this position by sending other diplomatic officials directly to Nepal while the Chinese ambassador to India and Nepal continues to reside in New Delhi, as provided in the agreement. The U.S.S.R., after dealing with Katmandu through Peiping, established formal diplomatic relations with Nepal in March 1957.

$140 \mathrm{By}$ the French delegate with reference to Vietnam, Cambodia, and Laos, SCOR 7th year, 602d meeting 16, 17 (S/PV.602/R.1) (1952), and by the Australian representative with reference to Ceylon, GAOR $3 d$ Sess., pt. 1, Ad Hoc Pol. Comm. 132 (A/AC.24/14) (1948).

141 There has been no greater profusion of writing and comment by international jurists than on the subject of recognition and the United Nations. Profusion has led to confusion, and there has been a tendency to deal with a variety of related, but nevertheless distinct, topics as one problem: these include recognition of states by other states; recognition of governments by other states; "collective recognition" by the United Nations; the recognition of credentials; the recognition of the representatives of a member state of the United Nations; recognition and the Stimson doctrine; recognition, intervention and self-determination. See, e.g., LAUTERPACHT, RECOGNITION IN INTERNATIONAL LAW (1947); MAREK, IDENTITY AND CoNTINUITY of States in Public International Law (1954); Aufricht, Principles and Practices of Recognition by International Organizations, 43 AM. J. INT'L L. 679 (1949); Briggs, Non-Recognition of Title by Conquest and Limitations on the Doctrine, 1940 Proc. Am. Soc'y INT'L L. 72; Kelsen, Recognition in International Law, 35 AM. J. INT'L L. 605 (1941); Wright, Recognition and Self-Determination, 1954 PROC. AM. SOC'Y INT'L L. 23. 
purposes of this Article, recognition is of importance only insofar as it relates to the "statehood" which is required for admission to comprehensive participation in the United Nations. Moreover, it must be viewed not as an all-explaining and mystical concept, but as another piece of evidence to be weighed in determining whether an entity is a "state" in relation to a specific claim. ${ }^{142}$

In connection with claims to admission to the United Nations, several delegations have emphasized the fact of widespread recognition or nonrecognition of an applicant state. Thus it was pointed out that the Republic of Korea had been afforded collective recognition as a state by the General Assembly by Resolution 195 (III), ${ }^{143}$ and had been recognized by more than thirty governments. ${ }^{144}$ Supporters of South Vietnam also emphasized that it had been recognized by more than forty states. ${ }^{145}$ It was likewise considered relevant that Mongolia was recognized not only by Russia and China, but also by India, Indonesia, and Burma. ${ }^{146}$

Perhaps the most interesting case in which the question of recognition was raised was that of Israel. The United States recognized the state of Israel immediately following the declaration of its independence. It was suggested in some quarters that this recognition was premature, ${ }^{147}$ being granted before it was possible adequately to ascertain all the facts. The United States delegate, however, insisted that the act of recognition was purely political, and could not properly be questioned. ${ }^{148}$ Other supporters of the admission of Israel cited

142 This inevitably begs some legal questions, especially the well-tried issue of the declaratory versus the constitutive view of recognition; for if recognition is indeed constitutive, its existence does not provide mere evidence of independence to be weighed along with other evidence, but being a prerequisite of statehood, it is also final proof. The controversy has been too voluminously discussed elsewhere to warrant further comment here. See, propounding the declaratory view, BRIGGS, ThE Law of Nations 109 (3d ed. 1942); LAUTERPaCHT, op. cit. supra note 141; Williams, La Doctrine de la Reconnaissance en Droit International et ses Développements Récents, 44 RECEUIL DES Cours 203, 237 (1933). The constitutive view is espoused in Redslob, La reconnaisance de l'Etat comme sujet de droit international, 13 RevUE DE Droit International 434 (1934); SpIRopoulos, Traité de DroIt InTERnatTonal Public 48 (1933). Suffice it to say that the author adheres to that view which regards recognition of statehood as declaratory of existing objective norms of international law and fact. No amount of recognition can make what is not a state into a state; and no amount of nonrecognition can convert what is a state-by all the legal criteria enunciated above-into a nonstate.

143 GAOR 3d Sess., pt. 1, Resolutions No. 195(III) (1948). For an interesting discussion of the effect of such resolutions on member states of the United Nationsincluding those who voted against the resolution-see Rosenne, Recognition of States by the United Nations, 26 BRIT. Yв. IN''L I. 437, 441 (1949).

144 GAOR 11th Sess., Spec. Pol. Comm. 77 (A/25) (1957).

145 Ibid.

146 GAOR 15th Sess., 988th meeting 41 (A/PV.988) (1961); GAOR 15th Sess., 989th meeting 8 (A/PV.989) (1961).

147 See MAREK, op. cit. supra note 141, at 156. See also Brown, The Recognition of Israel, 42 AM. J. INT'L L. 620 (1948).

148 In an oft-quoted statement, Representative Warren Austin declared: "I should regard it as highly improper for me to admit that any country on earth can question 
the fact of recognition as evidence of independence: both the Netherlands and Greece emphasized that they had recognized Israel, ${ }^{149}$ while Uruguay stressed that fifty-two nations had recognized the state of Israel by the time of the debate. ${ }^{150}$

United Nations practice undeniably reveals that most member states have considered the issue of recognition as relevant; this relevance, however, lies in the fact that it is useful evidence of the international status of an applicant, and the material available in no way implies that recognition is an essential prerequisite to independence. ${ }^{151}$

\section{Ciaim to Membership in the Specialized Agencies}

If the term "state" has no absolute fixed meaning, but rather takes on varying implications in accordance with the claim for which it is being used, then it is likely that entities which would not be considered states in relation to a claim for comprehensive participation in the United Nations might nevertheless satisfy the requirements of statehood where the claim is for limited participation. ${ }^{152}$ This is true although a successful claim under this head carries rights wider than the claim itself: an admitted member of a specialized agency derives additional rights to participate in conferences, become a party to treaties, and the like.

Not all of the constitutions of the specialized agencies provide that membership shall be limited to "states"; where they do not, questions as to their membership are beyond the scope of this Article. However, certain agency constitutions expressly use the term "state," ${ }^{153}$ and in

the sovereignty of the United States of America in the exercise of that highly political act of recognition of the de facto status of a state. Moreover, I would not admit here, by implication or by direct answer, that there exists a tribunal of justice or of any other kind, anywhere, that can pass upon the legality or validity of that act of my country." SCOR 3d year, 294th meeting 16 (S/749) (1948). In a later session, Mr. Jessup drew a distinction between the de jure recognition which had been given to the state of Israel and the de facto recognition that had been given to its provisional government. SCOR 3d year, 385th meeting 12 (S/1093) (1948).

149 GAOR 3d Sess., pt. 2, Ad Hoc Pol. Comm. 318, 323 (A/818) (1949).

$150 I d$. at 298.

151 No case study of the recognition of Communist China has been included under this head, in the belief that this is not a problem of statehood stricto senst, but rather a problem of the representation of an undeniably existent state, that of China. It is, of course, quite possible to approach the problem with the view that by now two separate states of China may exist.

152 Membership in the United Nations and in the specialized agencies are not automatically tied together; it is quite possible to be a member of a specialized agency without being a member of the parent organization. Likewise, it is possible to be a member of the parent without belonging to any of its offspring, although this raises no questions of statehood.

153 The membership requirements are as follows: International Atomic Energy Agency: "states members" of the UN or of specialized agencies who ratify within ninety days, other states upon approval of the General Conference after recommendation of the Board of Governors. STAT. InT'L Atomic EnERgy Agency art. IV, para B. 
these cases it is of interest to examine the membership of the agencies with a view to ascertaining how closely the traditional legal criteria have been followed. Such an examination will reveal that several entities whose international status is sufficiently in doubt for them never to have applied for admission to the United Nations, or for their application to have been refused, are nonetheless members of certain specialized agencies open only to states. Thus, the Republic of Korea is a member of the United Nations Educational, Scientific, and Cultural Organization (UNESCO), the World Health Organization (WHO), the International Civil Aviation Organization (ICAO), and the Universal Postal Union (UPU) ; the Republic of Vietnam is a member of the International Labor Organization (ILO), UNESCO, WHO, and UPU; Monaco is a member of UNESCO, WHO, and UPU; and San Marino and the Holy See belong to UPU. ${ }^{154}$

There are three alternative theories to explain the dilemma that some entities which are not states with respect to comprehensive participation do satisfy the statehood requirement for membership in the specialized agencies. First, this may be an example of political opportunism in treating as states entities which lack the basic characteristics which that term implies. Second, although political convenience may not have led to a failure to observe the fundamental juridical criteria of statehood, political intransigence may have led to the opposite abuse of denying admission to entities possessing the attributes of a state. Finally, and, it is suggested, most properly, the explanation may lie in an acknowledgment that a less rigorous interpretation of the term "state" is used when a limited claim is made than when comprehensive participation is sought.

International Bank for Reconstruction and Development: "countries." BANK ARTS. of AgreEment, art. 1. International Civil Aviation Organization: "contracting states" who ratify the convention. ICAO CONVENTION art. 48. UNESCO: members of the UN (automatic membership) or nonmember "states" who are admitted after a recommendation of the Executive Board by a two-thirds vote of the General Conference. UNESCO CoNst. art. 2. Food and Agriculture Organization: "nation." FAO Const. art. 2. World Health Organization: "membership . . . shall be open to all states." WHO ConsT. art. 3. International Labor Organization: "states." ILO Const. art. 2. International Maritime Consultative Organization: "states," associate membership available to "territories or groups of territories." IMCO CoNvENTION arts. 5-9. World Meteorological Organization: "territories and countries," under certain conditions. WMO CoNST. art. 3. International Monetary Fund: "countries." FUND ARTS. OF AGREEMENT art. 2. Universal Postal Union: "any sovereign country." UPU CONST. art. 3(1). International Telecommunication Union: original membership, "country or group of territories"; later membership, UN member "country," or non-UN member "sovereign country." ITU CoNvENTION art. 2.

154 Liechtenstein and Andorra, interestingly enough, are not members of any specialized agencies, although Liechtenstein maintains certain relations with the United Nations through the International Court of Justice. See notes 184-85 infra and accompanying text. It should perhaps be added that the Federal Republic of Germany-a "divided state" stricto sensil, but nonetheless recognized as a sovereign state by Russia-is a member of all those agencies restricted to "states." 
In support of the second theory, it has been argued that the reason that certain "divided states" are members of specialized agencies but not of the United Nations lies in the availability of the veto in the Security Council and its absence in the specialized agencies. While this seems a markedly realistic contention with respect to "divided states," the nonmembership of the "diminutive states" in the United Nations would seem to favor the view that the content of the term "state" may vary according to the claim involved, since these entities are inoffensive to both East and West. Nevertheless, it must in fairness be noted that none of the "diminutive states" has ever applied for membership in the United Nations itself, although there is the precedent of the rejection of the application of Liechtenstein for admission to the League of Nations. ${ }^{155}$ Ultimately, then, this question is still open for interpretation. However, since there is no need to accept the view that law has ceased to play a real role in problems of statehood in United Nations practice, I would reject it in favor of the theory that the membership in specialized agencies of certain entities which have been, or would have been likely to have been, refused membership in the United Nations is due to the necessity of interpreting the term "state" in the light of the claim being made and not to the opportunity for political abuse presented by the veto in the United Nations. ${ }^{156}$

It must also be remembered that a refusal to admit a nation to a specialized agency restricted to states may be made on other grounds

155 See note 103 supra.

156 The interpretation tentatively advanced here does entail the consequence that an applicant may be a "state" for some purposes and not for others. Whether or not this is desirable is a matter for discussion. It would seem to have advantages in that participation will not be refused to politically controversial applicants by organizations concerned with humanitarian work, if it is generally felt that "statehood" for this purpose does not necessarily constitute statehood for all purposes. How far membership in a specialized agency is in fact "the thin end of the wedge" to automatic acknowledgment of statehood in other contexts is not entirely clear from the available evidence. Certainly other consequences follow from limited participation-the new member will receive invitations to international conferences, will be able to be party to international treaties, etc. However, the consequences may still fall short of full participation. The future progress of Kuwait and Mauretania to membership in the United Nations may prove enlightening in this context. Kuwait, which has not yet applied for membership in the United Nations, is a member of UNESCO and ICAO; Mauretania, whose application was blocked by the Soviet veto due to the nonconsideration by the Security Council of the application of Mongolia-though in fact Mauretania's status may indeed be doubtful-has now been recommended for membership in WHO. WHO Press Release H/1685, Feb. 15, 1961.

Finally, it should be mentioned that the doctrine of estoppel may be relevant in this context. There would seem to be force in the contention that states voting for admission of an entity to an agency limited to "states" are estopped from denying its statehood in relation to any other claim to full sovereignty, such as to membership in the United Nations. However, in actual fact the entry into membership of specialized agencies by controversial entities is invariably accompanied by express reservations as to the limits of such recognition by those states who wish to protect their future positions on this issue, and there appears to be nothing objectionable in this practice. 
than that the entity is not a state; furthermore, the issue of statehood takes a place of lesser significance in a vote for admission to a specialized agency than it would in the consideration of a claim for comprehensive participation.

An examination of the practice of the agencies bears this out. By agreement with the United Nations ${ }^{157}$ applications for membership in UNESCO by states not members of the United Nations are transmitted to the Economic and Social Council (EcoSoc), which may recommend the rejection of such applications. UNESCO is bound to accept such a recommendation. ${ }^{158}$ The application of Austria was approved by the Council without comment, following an assurance that Austria was in fact entitled to enter into international agreements. ${ }^{150}$ The Council approved the applications of the Federal Republic of Germany, Japan, and Vietnam at its twelfth session, ${ }^{160}$ though certain delegates voiced the opinion that the very existence of West Germany was illegal, that Japan was incapacitated by the absence of a peace treaty, and that Vietnam was not a sovereign state representing the people. However, the view prevailed that a rigid adherence to technicalities was unnecessary. This was expressed in the comments of the representative of the United Kingdom, who thought that the aim of universality was of great importance, and that so long as the applicant had sufficient independence to conduct foreign affairs in its own name and was completely independent in that sphere of activity covered by the agency concerned, total independence was not necessary. ${ }^{101}$ The representative of Pakistan went even further, and thought that in view of the purposes of UNESCO, the applications should be considered from the standpoint of the advantages that the countries concerned might achieve. ${ }^{162}$ The application of Monaco is of special interest. EcoSoc, in giving its approval, ${ }^{163}$ recommended that UNESCO, in considering the application, should "take into account what contribution Monaco can make in furthering the programme of the Organization." 164 It further sug-

157 Agreement Between U.N. and UNESCO, July 10, 1948, art. 2, in 2 PEASLEE, INTERNATTONAL GoverNMENTAL ORGaNIZATIONS 724 (1956).

158 "[A]ny such recommendations shall be accepted by the Organization." Ibid. An interesting point arose in reference to the application of Ceylon as to whether EcoSoc could only reject applicants, or whether it could also recommend their admission. The latter interpretation prevailed. 3 REPERTORY OF PRACTICE OF UNITED Nations Organs 243 (1955).

159 U.N. EcoSoc Ofr. Rec. 4th Sess., Res. No. 59 (E/437) (1947).

160 U.N. EcoSoc OFF. REc. 12th Sess., 468th meeting 258-62 (E/1883), (E/ 1883/Add. 1 \& 2) (1951).

$161 I d$. at 258.

162 U.N. EcoSoc OFF. Rec. 12th Sess., 468th meeting at 260 (E/1883), (E/1883 Add. 1, 2) (1951).

163 U.N. EcoSoc OFf. Rec. 8th Sess., 129th Meeting 55 (E/568/Add. 1) (1948). $164 I d$. ann. 18. 
gested that UNESCO should consider "the general problem of the admission of similar diminutive States." 185

Similar provisions exist in the case of the International Civil Aviation Organization. Here the General Assembly has the power to reject an application. ${ }^{166}$ At its second session the Assembly approved the application of Austria, in spite of one representative's doubts as to Austria's freedom in the matter of civil aviation pending the signing of a peace treaty. ${ }^{167}$ Similarly, a resolution on Japan's admission was passed 53-0 with 6 abstentions. ${ }^{168}$

The practice of the World Health Organization is instructive in revealing a desire for universality which will blur the lines of statehood, but not reject them entirely. The application for membership by Monaco was accepted, after a report by the Legal Committee, but with emphasis that the decision was not to constitute a precedent. ${ }^{169}$ Vietnam was also admitted to membership, with little opposition being expressed. ${ }^{170}$ The application of the Republic of Korea met with the opposition that was to be expected from the representatives of the communist states. The United States emphasized the number of countries which had recognized South Korea, the fact that it was competent to conduct its own foreign affairs, and the desirability of universal membership. ${ }^{171}$ It was left to the Liberian representative to comment that "diseases know no national boundaries." 172 It is of interest, however, that the Report of the Working Party of the Committee on Constitutional Matters recommended that Sotth Korea be refused admission. ${ }^{173}$ The report was rejected. ${ }^{174}$ On the other hand, the Second Assembly of WHO refused to accept the application of San Marino, apparently on the ground that a reservation was attached as to the amount of financial contribution it could hope to make. Doubts had already been raised as to San Marino's statehood, and when these were combined with a financial inability to play a full role,

165 U.N. EcoSoc OFF. Rec. 8th Sess., 129th Meeting at ann. 18 (E/568/Add. 1) (1948). That this resolution has borne fruit may be seen in the fact that the application of Kuwait has also received the blessing of the council. U.N. EcoSoc OFF. REC. 30th Sess., Supp. No. 1 (E/3422) (1960).

166 Agreement between UN and ICAO, May 31, 1948, art. 2, in 2 PEASLEe, op. cit. supra note 157 , at 75 .

167 GAOR $2 d$ Sess., Plenary 562-64 (A/434) (1947).

168 GAOR 7th Sess., Plenary 182-83 (A/2176 \& Add. 1) (1952). Note also that Kuwait became the seventy-eighth member of ICAO on June 17, 1960. ICAO News Release, June 17, 1960.

169 WHO OfF. REc. 1st Ass., Plenary 10th meeting 76 (1948).

170 WHO OfF. REC. 3d Ass., Plenary 5th meeting 126-27 (1950).

171 WHO OfF. Rec. 2d Ass., Plenary 10th meeting 122-23 (1949).

172 Id. at 123.

173 WHO OFF. REc. 2d Ass., Comm. on Constitutional Matters 10th meeting 312 (A/L612) (1949).

174 Id. at 312-14. 
it was decided to reject an applicant who was offensive to none on political grounds. ${ }^{175}$

The records of the selection committee of the International Labor Organization show a very detailed examination of the legal eligibility of applicants. It regarded as relevant in its recommendation to admit Vietnam the fact that that state was widely recognized and that its government controlled three-fifths of the territory of the country and four-fifths of the population. ${ }^{170}$ The French delegate, discussing the report, emphasized the fact that since France was no longer in a position to implement the internal administration of Vietnam, the labor conventions which had been concluded by France and applied to Vietnam would lapse if Vietnam were not admitted. ${ }^{177}$ This realistic approach carried force. ${ }^{178}$ The discussions of the application of the Federal Republic of Germany reveal a sharp division of opinion. The United States representative emphasized the desirability of universality, and the United Kingdom representative viewed admission as a commitment by the applicant to democratic ways. Israel opposed the admission on nonlegal grounds, while the Czechoslovakian and Polish delegates declared themselves dissatisfied with the international status of the Federal Republic of Germany. ${ }^{179}$

It can thus be seen that in relation to this limited claim, the term "state" has a less distinct relationship to the traditional legal criteria than when used in reference to comprehensive admission to the United Nations. Partial lack of independence may be compensated for by an ability to fulfill the aims of the particular agency, ${ }^{180}$ or by an overriding policy consideration of the desirability of universality of membership. ${ }^{181}$

175 Working Party, Report, WHO OFf. Rec. 2d Ass., Comm. on Constitutional Matters, 10th meeting 312 (1949).

176 Selection Comm., 10th Report, Int' Labor Conf. Rec. Proc. 33d Sess., pt. 3 (app. II) 403 (1950).

177 Id. pt. 2, at 187.

178 The resolution was carried 132-0, 11 abstentions. Selection Comm., 10th Report, InT'L Labor Conf. Rec. Proc. 33d Sess., pt. 2, 191 (1950). The Indian delegate announced that he would support this application, but would also have supported one from Vietminh, as universality was paramount.

179 The Czechoslovakian government delegate pointed out that sovereignty could not be conjured up by the letter from the Secretary General of the Allied High Commission for Germany stating that in the event of admission, the Commission would not exercise any of the powers reserved to it under the Revised Occupation Statute in such a way as to prevent or hinder the fulfilment of the responsibilities of the Federal Republic of Germany attaching to membership in the ILO. Vis-á-vis a claim for comprehensive admission, one must concede a certain cogency in this argument. The resolution in favor of admission was carried 165-12. Selection Comm., 3d Report, INT'L Labor Conf. Rec. Proc. 33d Sess. 506 (1950).

180 For a concise summary of the aims of the various specialized agencies of the United Nations, see Asmer, United Nations and Economic and Social CooperaTION, app. B (1954).

181 Similar trends in other specialized agencies may also be traced. Thus the Federal Republic of Germany is also a member of the Intergovernmental Maritime 
Clamms To Be Party to the Statute of the International Court of Justice

Article 93 of the United Nations Charter states:

1. All Members of the United Nations are ipso facto parties to the Statute of the International Court of Justice.

2. A State which is not a Member of the United Nations may become a party to the Statute of the International Court of Justice on conditions to be determined in each case by the General Assembly upon the recommendation of the Security Council.

Consequently, it seems that if an entity which is not a member of the United Nations applies to become a party to the Statute of the Court under Article 93(2), the issue of its statehood must be passed upon. Further, Article 35(2) of the Statute of the Court provides:

The conditions under which the Court shall be open to other States [i.e., those not parties to the Statute] shall, subject to the special provisions contained in treaties in force, be laid down by the Security Council, but in no case shall such conditions place the parties in a position of inequality before the Court.

Here again, the reference is to "states," and is consonant with Article $34(1)$ of the Statute. ${ }^{182}$ Although neither Article $93(2)$ of the Charter nor Article 35(2) of the Statute refers to independent states, both a contextual reading of the instruments and state practice ${ }^{183}$ confirm that this is what was meant by the authors.

Consultative Organization, which restricts full membership to "states." IMCO Const. arts. 5-9. At its second session, on March 2, 1960, the IMCO Council upheld the position of the Secretary General of that Organization that the application for membership of the Democratic Republic of Germany contained in letter of January 25,1960 , was to be refused. The ground given was lack of sovereignty. The arguments of the applicant that no discretion as to membership was left to the organization and that sea power was the paramount consideration did not prevail. Further correspondence on behalf of the applicant is contained in a letter of April 30, and reproduced in a letter of June 16, 1960, from the Secretary General which was circulated to the Secretary of State of the United States government. Monaco, Korea, and Vietnam are members of the International Atomic Energy Agency, whose membership provisions refer only to "states" and, further, declare that "the Agency is based on the principle of the sovereign equality of all its members." IAEA STAT. art. IV(c). For practice of the Universal Postal Union with regard to Estonia, Latvia, and Lithuania, see UPU, Report, EcoSoc OFF. REc. 7th Sess., 220th meeting (E/811), (E/1030) (1947).

182 "Only States may be parties in cases before the Court."

183 This is illustrated in Rosenne, The Internationad Court of Justice 235-36 (1957), which cites the fact that in the United States Nationals in Morocco Case, [1951] 'I.C.J. Rep. 109, 110, the applicant government, France, specifically stated in answer to a query from the court, that the French Republic was proceeding both on its account and as protecting power in Morocco, the judgment to be "binding upon France and Morocco." Rosenne also cites The Minquiers and Ecrehos Case, [1953] I.C.J. Rep. 47; The Mavrommatis Palestine Concessions, P.C.I.J., ser. A, No. 2 (1924); Tunis-Morocco Nationality Decrees Case, P.C.I.J., ser. B, No. 4 (1923); 
A claim to become a party to the Statute of the Court is a claim to limited participation. A fortiori, this is true of a claim to appear before the Court on a single occasion. The undoubted desirability of having as many states as possible subject to the compulsory jurisdiction of the Court and, reciprocally, with access to the Court, together with the fact that the claim is of a limited nature, provide the expectation that in this context the term "state" will be interpreted liberally, that is, will bear a slightly less distinct relationship to the formal legal criteria of statehood. Practice bears out this expectation; both Liechtenstein and San Marino are parties to the Statute of the Court under Article 93(2). ${ }^{184}$ The application of Liechtenstein received some opposition, mainly on the ground that it does not conduct its own foreign relations, from which it was argued that it was not an independent state. ${ }^{185}$ The application of San Marino was also opposed in some quarters, ${ }^{186}$ one of the reasons being that it was a diminutive state. For these reasons, inter alia, the U.S.S.R. abstained from voting in the Security Council. It also abstained from voting on the Japanese application, ${ }^{\mathbf{1 8 7}}$ on the ground that Japan's sovereignty at the time was to be doubted by reason of the fact that that country maintained no diplomatic relations with the Soviet Union. ${ }^{188}$ However, the majority of the Security Council and General Assembly felt that these nations possessed sufficient international status for them to be deemed "states" for the purposes of Article 93(2); accordingly, they became parties to the Statute ${ }^{189}$ on the same conditions as had been laid down for Switzerland.

The Oscar Chinn Case, P.C.I.J., ser. A/B, No. 63 (1934); and the Phosphates in Morocco Case, P.C.I.J., ser. A/B, No. 74 (1938), as evidence of the fact that only independent states may be parties in cases before the court. $\mathrm{He}$ points out that not all international tribunals have denied dependent states possessing some measure of international personality the procedural capacity to appear before them: thus in the Ottoman Public Debt Arbitration (Bulgaria, Iraq, Palestine, Transjordan, Greece, Italy, Turkey), 1 U.N. Rep. Int'l Arb. Awards 529 (1925), the Ievant states under French mandate and Iraq, Palestine, and Transjordan under British mandate, were parties.

184 The first nonmember of the United Nations to be a party to the court's Statute was Switzerland, whose status as a state was, of course, never in doubt. The Security Council recommended that it become a party on condition it accept the Statute and the obligations of Article 94 of the Charter, and contribute to the expenses of the court. SCOR 1st year, 2d ser., Supp. No. 7, at 157 (S/185) (1946); GAOR 1st Sess., pt. 2, Resolutions No. 91 (A/64) (1946).

185 SCOR 4th year, 432d meeting 3 (S/1342) (1949); GAOR 4th Sess., 6th Comm. 214 (A/967) (1949).

186 SCOR 8th year, 641st meeting 2 (S/3137) (1953).

187 Japan subsequently became a member of the United Nations in December 1956; hence Japan is now a party to the Statute of the court under Article 93, para. 1 of the Charter.

188 SCOR 8th year, 641st meeting 2 (S/3126) (1953).

189 GAOR 4th Sess., Resolutions No. 363 (A/1251) (1949) (Liechtenstein); GAOR 8th Sess., Resolutions No. 805 (A/2630) (1953) (Japan); GAOR 8th Sess., Resolutions No. 806 (A/2630) (1953) (San Marino). 
The same tendency is revealed in practice under Article 35(2). A number of general declarations have been filed in accordance with treaties which provide for settlement of disputes as to their provisions by the Court. ${ }^{190}$ In short, the term "state" used in reference to this claim, has the liberal content which one would expect under the circumstances. ${ }^{101}$

\section{Other Claims}

The existence of statehood is relevant to a claim to appear before the Security Council by a nonmember of the United Nations, since invitations to participate in discussions on a dispute to which the nonmember is a party are governed by Article 32 of the Charter, which limits such participation to states. ${ }^{192}$ The invitation extended to the Republic of Indonesia is the most interesting case study here. Considerable diversity of opinion existed as to whether the Republic of Indonesia should be invited to participate in the work of the Security Council concerning the hostilities between Indonesia and the Nether-

190 In accordance with article 22 of the treaty of peace with Japan, Sept. 8, 1951, [1952] 3 U.S.T. \& O.I.A. 3172, 136 U.N.T.S. 46, 72 (1952), general declarations have been filed by Vietnam, Nov. 5, 1952, 150 U.N.T.S. 147 (1952), which is still not a member of the United Nations and whose status may be in doubt by Japan, Nov. 24, 1951, Ceylon, April 23, 1952, and Cambodia, July 17, 1952, 137 U.N.T.S. 4, 8,12 (1952), which did not become UN members until 1955 (Ceylon and Cambodia) and 1956 (Japan), and whose status as states was subject to some controversy at the time.

191 Rosenne, op. cit. supra note 183, at 235, observes that "unlike States whose status as parties to the Statute follows from Articles 3, 4, or 93(2) of the Charter, statehood of states appearing before the Court under Article 35(2) of the Statute is not the subject of a preliminary political and binding decision by the General Assembly upon the recommendation of the Security Council." $\mathrm{He}$ suggests that their statehood may be challenged, leaving the court with the task of deciding the question. He extends the doctrine of implied recognition even further by stating that the court may even be called upon to pass upon the statehood of a state simply by virtue of exercising the depositary function for these declarations. He declares that as no specific provisions exist as to the form or emanation of this declaration, the matter must be presumed to be governed by general international law, according to which the declaration should come from the head of state or foreign minister of a recognized state. The more general view would be to consider that the Registrar of the court possesses no legal discretion, but is performing an administrative function without prejudice to the incidental issues involved.

192 Article 32 reads: "Any Member of the United Nations which is not a member of the Security Council or any State which is not a Member of the United Nations, if it is a party to a dispute under consideration by the Security Council, shall be invited to participate, without vote, in the discussion relating to the dispute. . . ." Invitations under article 32 were issued to Albania with regard to the Corfu Channel incident, SCOR 2d year, 95th meeting 123 (S/247) (1947) and to Jordan concerning both the Palestine question, SCOR 5th year, 511th meeting 1-2 (S/PV.511) (1950), and the Israeli-Jordan exchanges of complaints, SCOR 9th year, 670th meeting 13 (S/PV.670) (1954). Yet controversies as to their respective statuses were still present in relation to the comprehensive claim of admission. At one point, the representative of the Arab Higher Committee stated that since the President of the Security Council (the Ukrainian delegate) had referred to the representative of the Jewish Agency as the representative of the State of Israel, he would take no further part in the deliberations. SCOR 3d year, 330th meeting 10 (S/PV.330) (1948). 
lands. ${ }^{193}$ The representative of the Netherlands was firmly opposed to such an invitation, insisting that it would prejudge the issue of statehood, which was the very question in dispute. The Republic of Indonesia was not, he asserted, a sovereign state. ${ }^{104}$ The Australian delegate thought otherwise. ${ }^{195}$ Most significant was the diverse support ${ }^{198}$ to be found for the view of the Indian delegate that there can be states without full sovereignty which are states for the purposes of chapter seven of the Charter. ${ }^{197}$ Ultimately an invitation was issued, but under no specific rule or article. ${ }^{198}$

Claims to appear before the Security Council may also be made under the terms of Article 35(2) of the Charter. ${ }^{109}$ The complaint by Hyderabad of Indian aggression ${ }^{200}$ is the only significant case in this category. The question arose as to whether it was possible to invite Hyderabad-whose status as an independent state was very seriously in doubt-to appear before the Security Council, or indeed,

103 The representatives of both Australia and the U.S.S.R. thought that an invitation should be extended under article 32 . SCOR $2 d$ year, 171st meeting 1618, 1627 (S/446/Corr.1) (1947).

194 "The Republic of Indonesia is not a sovereign State any more than the State of Eastern Indonesia or of Borneo . . . . It is a political entity to be affiliated ultimately with the two other states $I$ have named, and to be part of a federation. .. [It is comparable] to New York, or Utah, or New South Wales...." $\dot{I} \dot{d}$. at $1619-20$.

$195 \mathrm{He}$ cited the following factors as proof of statehood: (1) The government of Indonesia had been recognized by the Netherlands government as exercising $d e$ facto authority over Java, Madura, and Sumatra. (2) The Republic of Indonesia had been given de facto recognition by a number of other governments, including the United Kingdom, the United States, India, Australia, and members of the Arab League. (3) Article XVII of the Linggadjati Agreement provided for the selection of an arbitration body by the President of the International Court; yet only states may appear before that court. (4) EcoSoc had passed a resolution with regard to the ITO, inviting the Indonesian government to the Havana Conference. SCOR 2d year, 171st meeting 1623-24 (S/446/Corr.1) (1947). These last two points would appear to be of doubtful validity. To be a party to arbitration arranged by the President of the International Court is not the same as appearing before that court. Furthermore, participation in the ITO is not restricted to states.

196 From the representatives of Australia, China, Syria, United States, and U.S.S.R.

197 SCOR 2d year, 171st meeting 1628 (S/446/Corr.1) (1947).

198 From the discussion that followed it became clear that the Netherlands government thought the invitation was under neither article 32 nor rule 39; Belgium thought it was based on grounds of equity and justice; while Australia, Poland, and the U.S.S.R. thought it was based on article 32. Under Rule 39 of the Provisional Rules of Procedure, the Security Council "may invite members of the Secretariat or other persons, whom it considers competent for the purpose, to supply it with information or to give it assistance in examining matters within its competence." Quaere whether representatives of purporting states may be invited under rule 39 , or whether it is only applicable to individuals stricto sensu. The Polish delegate was of the latter view. SCOR 2d year, 181st meeting 1941-42 (S/487) (1947).

199 "A State which is not a Member of the United Nations may bring to the attention of the Security Council or of the General Assembly any dispute to which it is a party if it accepts in advance, for the purposes of the dispute, the obligations of pacific settlement provided in the present Charter."

200 SCOR 3d year, Supp. Sept. 1948, at 5 (S/986) (1948). 
whether the complaint of Hyderabad could even be admitted to the agenda without prejudging the issue. ${ }^{201}$ Eventually Hyderabad was invited to send a representative to appear before the Security Council. Here it again may be seen that for the purposes for which the term was invoked, it was thought neither necessary nor desirable to adhere rigidly to the traditional legal criteria of statehood.

With regard to the General Assembly, neither the Charter nor the Rules of Procedure of the Assembly provide explicitly for the participation of nonmember states. However, the status of an entity may be brought indirectly into issue by virtue of the fact that Article 11 does provide that the Assembly may consider matters brought before it in accordance with Article 35(2)-which employs the term "state." Although no nonmember state has been invited to participate in the plenary sessions of the General Assembly, certain invitations have been extended to participate in committees. Invariably caveats were attached denying implied acknowledgment of statehood. No clear conclusions can be drawn from an examination of practice under this head. ${ }^{202}$

201 See Eagleton, The Case of Hyderabad Before the Security Council, 44 AMr. J. INT'L L. 277 (1950). The Indian representative stated that Hyderabad is not a state; that it is not independent; that never in all its history did it have the status of independence; that neither in the remote past, nor before August 1947, nor under any declaration made by the United Kingdom, nor under any act passed by the British Parliament has it acquired the status of independence which would entitle it to come in its own right to present a case before the Security Council. SCOR 4th year, 425th meeting 2-8 (S/1317) (1949).

202 Reference may be made to the fact that the Arab Higher Committee and the Jewish Agency for Palestine attended meetings of the First Committee, GAOR 1st Spec. Sess., 1st Comm. 107-19 (A/C.1/036) (1947). Italy, whose sovereignty may possibly have been impaired by the armistice arrangements, participated in the Fourth Committee as administering authority for the trust territory of Somaliland. GAOR 5th Sess., 4th Comm. 195 (A/1294) (1950). Transjordan participated in discussions on the problem of the establishment of the state of Israel. GAOR 3d Sess., pt. 1, Ist Comm. 160 (A/648) (1948). The Republic of Korea has also participated. GAOR 3d Sess., pt. 1, 1st Comm. Annex 64 (A/1294) (1950). A resolution to invite representatives of North Korea was rejected, partly on the grounds that neither the state nor government of North Korea was recognized by the United States. It is of interest that Article XI of the Genocide Convention provides that the General Assembly may invite nonmember states to become parties. GAOR 3d Sess., pt. 1, Resolutions No. 260(III), at 175 (1948). It was pointed out by certain representatives in the Sixth Committee that to invite all "non-member states" would place the Secretary General in the very delicate position of having to prepare a list of all the nonmember states in the world. GAOR 4th Sess., 6th Comm. 450-62 (A/942) (1949). It was finally decided to invite active members of the specialized agencies of the United Nations. See GAOR 4th Sess., Plenary, Annex 211 (A/1168) (1949). As can be seen from the discussion at pp. 1156-61 supra, this does not avoid the problem of passing on the statehood of the country concerned-it merely delegates elsewhere the responsibility of making such a decision. Sir Gerald Fitzmaurice pertinently pointed out that the expression "non-member states" meant sovereign, independent states, responsible for the conduct of their own foreign relations; since some entities which did not fulfill these conditions might be members of certain specialized agencies, some amendment or specification was needed. In any event, Korea, Monaco and Vietnam have become parties to the Genocide Convention, though they are still not members of the United Nations. GAOR 4th Sess., 6th Comm. 455 (A/942) (1949). 
Other claims which can give rise to the issue of statehood may also be noted at this juncture. The various regional economic commissions of the Economic and Social Council have membership which includes entities less than full states. However, in each case express provisions allowing for membership of nonindependent territories cover the case, and no implication of statehood arises. ${ }^{203}$ The functional commissions of EcoSoc normally consist of the representatives of member states of the United Nations or experts serving in an individual capacity; occasionally members of specialized agencies may be elected to serve, and here again that membership has been open to a country whose status undoubtedly would be queried were it claiming full admission to the United Nations. ${ }^{204}$

The Secretariat too may find itself faced with an implicit claim to statehood. Thus under Rule 6 of the Provisional Rules of Procedure of the Security Council, the Secretary General is required to bring to the attention of the Council "all communications from States . . . concerning any matter for the consideration of the Security Council in accordance with the provisions of the Charter." 205

Provision has been made for the filing and publication by the Secretary General of treaties registered under Article 102 of the Charter. If the Secretary General has any discretion in the matter, he may be called upon to decide whether an instrument does indeed emanate from the government of a sovereign state, and is thus a treaty which warrants registration. A cursory examination reveals that treaties and agreements to which nonmember states whose very statehood was in doubt are parties have indeed been registered with

203 Thus the Economic Commission for Africa has Gambia, Kenya, Zanzibar, Sierra Leone, and Tanganyika as associate members. The Federal Republic of Germany is a full member of the Economic Commission for Europe, and representatives of the Eastern Zone of Germany participate in a consultative capacity in the work of ECE's subsidiary organs. The Republics of Korea and Vietnam are members of the Economic Commission for the Far East.

204 Thus the Federal Republic of Germany was elected to serve on the Technical Assistance Committee and has also been a member of UNICEF, a special body of the Economic and Social Council.

205 A complaint from Siam prior to her admission to the UN was circulated under Rule 6. U.N. Doc. No. S/106 (1946). A communication from Hyderabad was circulated with an attached note from the Secretary General stating that he was not in a position to determine whether he was required to circulate it under Rule 6. SCOR 3d year, Supp. Sept. 1948, at 9 (S/1015) (1948). And the Secretary General has circulated a note from the Democratic Peoples' Republic of Korea, with a prefatory note stating that it was not a circulation under Rule 6. U.N. Docs. Nos. S/1247, S/1256 (1949). In short, every possibility has been covered in practice. See REPERTOIRE OF THE PRACTICE OF THE SECURITY COUNCIL 1946-1951, at 65 (ST/PSCA/1) (U.N. Pub. Sales No. 1954.VII.1). For more detailed comments on Secretariat practice under Rule 6, see Schachter, The Development of International Law Throngh the Legal Opinions of the United Nations Secretariat, 25 BRIT. YB. INT'L L. 91, 115-22 (1948). 
the Secretariat; ${ }^{206}$ but on no occasion has such a treaty been registered by the nonmember party. ${ }^{207}$

\section{ConCLUSION}

The real significance of a discussion of the concept of statehood in United Nations practice can be seen by examining the interaction between two viewpoints which have been advocated throughout this Article. Thus the main thesis advocated here is that variations in United Nations practice concerning claims of statehood are a result not of an abandonment of traditional legal criteria of statehood but of the proper use of flexibility in interpreting these criteria in relation to the claim in which they are presented. ${ }^{208}$ Concomitantly, the basic criteria of population, fixed territory, stable and effective government, and sovereign independence have been-and should be-followed quite closely.

The resulting problem can be best seen by reexamining the requirement of independence; more specifically, the problem is illustrated by the difficulties which arise from the conjunction of a theory that the criteria of statehood must be observed and the view that actual-rather than formal-independence is necessary before an entity may properly be called a state.

206 E.g., Agreement Between New Zealand and Monaco Concerning the Mutual Abolition of Visas, 171 U.N.T.S. 270 (registered by New Zealand); Agreement Between the United States and Monaco Relating to Reciprocal Waiver of Passport Visa Fees for Non-Immigrants, March 31, 1952, 177 U.N.T.S. 194 (registered by the United States).

207 Rosenne, Recognition of States by the United Nations, 26 BRIT. YB. INT'L L. 437, 444 n.3 (1949), notes that the Linggadjati Agreement signed at Batavia on March 25, 1947, between the Netherlands and the Republic of Indonesia, was not submitted by either party for registration. Rosenne suggests that had it been submitted by Indonesia, which was not a member of the UN, the Secretary General would have had to exercise a discretion and observes that once the Security Council had decided to invite the representatives of the Government of Indonesia to its meetings, it would have been virtually impossible for the Secretary General to refuse to accept a treaty submitted by the same representative for filing and publication. The present writer is of the opinion that no discretion exists in this area. See the caveat appearing prefatory to the United Nations Treaty Series: "Registration of an instrument submitted by a member state, therefore, does not imply a judgment by the Secretariat on the nature of the instrument, or the status of a party, or any similar question."

208 Thus, although there was no doubt that representatives of South Molucca were both willing and able to appear before the Security Council in connection with the Indonesian question, and would have been most useful, it was not possible to issue such an invitation. N.Y. Times, April 25, 1952, p. 22, col. 2; id., Nov. 4, 1952 , p. 11, col. 4. Similarly, should an attempt at participation, either limited or comprehensive, be made by the "Nations of the Iroquois" it could not be entertained. In 1923 an appeal to the League of Nations was presented on behalf of the "Six Nations of the Iroquois" which sought relief against Canada and which claimed to be a "state" within the meaning of article 17 of the Covenant. In a letter dated February 7, 1924, the Secretary of State for External Affairs of Canada discussed the status of these Indians and maintained that they could not be regarded as a "state." Apparently no action was taken by the League. See LEAGUE of NATIONS OFF. J., 7th Ass. 829-42 (1924). See also United States v. Sandoval, 231 U.S. 28, 46 (1913); Andrews v. State, 192 Misc. 429,79 N.Y.S.2d 479 (Ct. Cl. 1948), aff'd, 276 App. Div. 814, 93 N.Y.S.2d 705 (1949). 
The stress placed on the requirement of actual independence is supported not so much by United Nations practice as by its inherent superiority as a criterion for determining whether an entity should properly be a subject of international law. Thus it is of no particular concern either that the formal rhetoric of the discussions of the earlier years of the United Nations undeniably made use of the concept of actual independence or that the recent tendency not to examine this criterion too closely suggests that the stress on actual independence was merely a convenient contention to make during the hotter stages of the cold war.

What is important is that policy questions will have to be decided during the years to come; and in the future-even if this was not so in the past-the definition of independence will have real relevance. There would seem to be very good grounds for insisting upon the importance of actual independence; not only will such a policy keep more firm the marriage between law and fact, but it will also prevent certain abuses of the right of popular self-determination which might otherwise occur. It may, for example, be insufficient to rest satisfied with the formal announcement of independence granted to a territory by an ex-colonial power, for if in fact true independence is not also present, to allow admission to the United Nations may actually perpetuate the voice of the former colonial power and prevent real selfdetermination, though the intended effect was the opposite.

Actual independence is perhaps the most difficult of all the criteria of statehood to assess correctly; in some cases it may well be impossible of objective ascertainment. Consequently, a decision to concede the existence of "statehood" in regard to any given claim may have to turn on nonlegal factors. In the hope that these would be other than arbitrary political acts of self-advancement, it may be advantageous to enunciate certain policies which should be kept in mind :

(1) As many entities as possible should be represented on and participate in the work of a near-universal international organization. This is especially true in the light of Articles 2(6) and 39, which extend the scope of action of the United Nations beyond the immediacy of its own membership. This policy is also in keeping with changing trends as to the subjects of international law, the movement being away from the traditional idea that international law is a legal order solely relevant to sovereign states.

(2) As many entities as possible should be made responsible to the world organization, one of whose primary responsibilities is the maintenance of international peace and security. 
These suggested policies raise a host of related questions, such as the relative advantages of universality and selectivity. Although Article 4 of the United Nations Charter rejects the idea of automatic universality, it was recognized at San Francisco that universality was "an idea towards which it was proper to aim." 209 The merits and demerits of universality as both a philosophical and political concept have been fully argued elsewhere; ${ }^{210}$ nor is the experience of the League of Nations in this matter uninstructive. ${ }^{211}$ Quite apart from the moral desirability of having entities which may be subject to a sanctioning process represented on the organ which metes out such sanctions, we must ask ourselves: Is a near-universal membershipmore specifically, membership of certain politically troublesome entities-liable to lead to a greater conformity with international law? Nonadmission of a number of countries could lead to the formation of a rival group of nations outside the United Nations. The collective security and disarmament arrangements of the United Nations might well be ameliorated by a more comprehensive participation. On the other hand, a mechanical addition of members does not always add to the strength of the association; differing ideologies within one family may accentuate mistrust, and frequent conflicts within an organization may weaken or paralyze its functions. While League experience clearly illustrates that membership per se is no guarantee of good behavior, by and large it is probably more conducive to peace to have a potential aggressor within the organization than outside it. The other member states would then be able to negotiate directly and immediately; in addition present members might agree to inclusion from a belief that the membership of a major ally of an opponent would increase the opportunities for driving a wedge between the admitted state and its allies or for weakening the support of the domestic rank and file. Isolation of an entity allows the existing elite of that country to maintain complete control of communications, and

209 Doc. No. 1178, I/2/76(2), 7 U.N. CoNf. INT'L Org. Docs. 326 (1945).

210 See, e.g., Schwarzenberger, The League of Nations and World Order (1936) ; Green, Membership in the United Nations, in 2 Current Legal Problems 258 (Keeton \& Schwarzenberger eds. 1949).

211 An Argentinian motion in the League Assembly maintained that "the strength of the League of Nations depends on its including the greatest possible number of states." LEAGUE of NATions OFF. J., 1st Ass. 234 (1920). The League appeared to tend towards inclusivity in the hope that standards of behavior could thus be raised, and often demanded solemn declarations from applicants for admission. Thus Abyssinia, which was indulging in the slave trade at the time of application in 1923, was required to sign a declaration adhering to the obligations of the Convention of St. Germain-en-Laye, Sept. 10, 1919, 8 L.N.T.S. 26 (1922), concerning slave trade, before she was admitted. LeAGUe of NATrons OFF. J., 4th Ass. 376 (1923). Many newly created European states, such as Estonia, Finland, Latvia, and Lithuania, were required to sign declarations binding themselves to respect the rights of minorities within their borders. 
it becomes difficult in the extreme to foster liberalizing elements without substantial international intercourse.

While I would favor policies of maximum representation and responsibility, the argument that these run the risk of allowing a country to "blackmail its way into the organization" through adverse behavior remains a real one. No a priori answer for every applicant is possible; but with the general policies in mind, each case where the existence of actual independence is not entirely clear should be examined and such questions should be asked as: Who has been affected by a lack of international cooperation? To what extent has the applicant sought to thwart, or to promote, the objectives of the organization? What effect has such conduct had on the micropowers and on the "uncommitted" nations? What kinds of considerations are involved that would allow the United Nations to forego certain values-such as a dislike of "moral blackmail"-in order to consolidate others? Are there historical data available to support the contention that exclusion fosters isolation? What distinction is to be found between rhetoric and substantive policy on this issue on the part of the Great Powers?

In addition to universality and promotion of world peace, three other policies are relevant to the choice to extend or limit admission to the United Nations and its subordinate organs: the belief that all peoples have a right to self-determination, the desirability of making every effort to insure international cooperation in as many fields as possible, including economic and social fields, and the necessity of taking all reasonable steps to insure the smooth working of the United Nations and its various functions.

It must be noted that in certain cases there may be a conflict among these policies: thus it may be necessary to make a choice between wider representation of peoples and administrative efficiency. The final solution may be made easier by the fact that the first three policy considerations are immediately pertinent to claims to comprehensive participation, while claims to limited participation, especially in organs of a technical character, would seem to indicate that priority should be given to the last two considerations.

No panacea is offered; at most the suggested policies can provide guidelines. But if United Nations practice in matters of statehood is to reveal a purposeful welding of law and politics and is to develop an emphasis upon true independence, guidelines will be needed. 